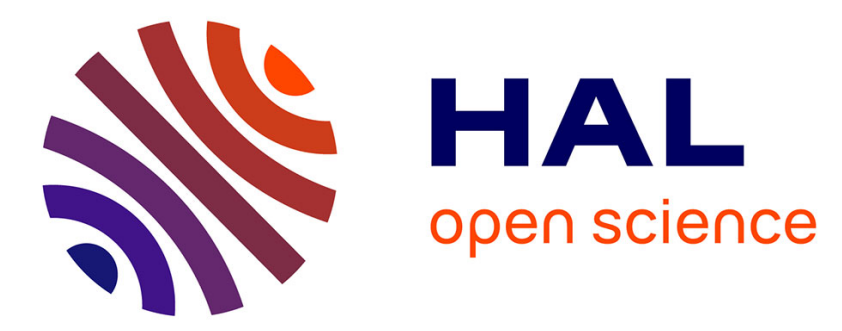

\title{
Dynamics and microphysics of orographic precipitation during MAP IOP3
}

Olivier Pujol, Jean-Francois Georgis, Michel Chong, Frank Roux

\section{To cite this version:}

Olivier Pujol, Jean-Francois Georgis, Michel Chong, Frank Roux. Dynamics and microphysics of orographic precipitation during MAP IOP3. Quarterly Journal of the Royal Meteorological Society, 2005, 131 (611), pp.2795-2819. 10.1256/qj.04.79 . hal-00023212

\section{HAL Id: hal-00023212 \\ https://hal.science/hal-00023212}

Submitted on 17 Sep 2021

HAL is a multi-disciplinary open access archive for the deposit and dissemination of scientific research documents, whether they are published or not. The documents may come from teaching and research institutions in France or abroad, or from public or private research centers.
L'archive ouverte pluridisciplinaire HAL, est destinée au dépôt et à la diffusion de documents scientifiques de niveau recherche, publiés ou non, émanant des établissements d'enseignement et de recherche français ou étrangers, des laboratoires publics ou privés. 


\title{
Dynamics and microphysics of orographic precipitation during MAP IOP3
}

\author{
By OLIVIER PUJOL*, JEAN-FRANCOIS GEORGIS, MICHEL CHONG and FRANK ROUX \\ Laboratoire d'aérologie, Observatoire Midi-Pyrénées, Toulouse, France
}

\section{SUMMARY}

A dynamical and microphysical four-dimensional study of an intense orographic precipitating system is carried out in the frame of MAP IOP3 (25-26 September 1999). High precipitation opportunely occurred in the range of the Swiss operational Doppler radar at Monte Lema (Switzerland), the US SPOL polarimetric Doppler radar and the French Ronsard Doppler radar both located near Lago Maggiore (Italy). Radar data have been combined to deduce four-dimensional precipitation and wind fields during the most intense precipitation period (1600-2000 UTC on 25 September). The organization and evolution of the microphysical field have been obtained through an analysis of SPOL polarimetric data: nine hydrometeor classes (light, moderate and heavy rain, hail, rain-hail and graupel-hail mixtures, dry and wet snow, and ice crystals) are inferred by means of a fuzzy-logic method initially developed by Vivekanandan $\mathrm{et} \mathrm{al}$.

The temporal mean study of reflectivity fields reveals that the precipitation presents a convective pattern and is primarily located on the foothills and over the first mountain. Mean microphysical fields reveal rain below the $0{ }^{\circ} \mathrm{C}$ level, wet snow, ice crystals and dry snow above with an embedded $2 \mathrm{~km}$ deep layer of graupel-hail mixture. This suggests convective microphysical processes.

Temporal series of precipitation and wind fields are then analysed in order to characterize in detail the organization and evolution of the system. Three stages were identified: first an elongated structure growing and intensifying over the lake while moving towards the Alps, then a spreading of the system over the mountains and finally a weakening over Lago Maggiore and the mountains. It has to be noted that the lake and the first mountainous peaks were important factors in the generation and the intensification of convective cells: the lake acts as a secondary moisture source which can favour local convection, and mountainous slopes favour updraughts which permit a downwind extension of the system by ejection of precipitating particles according to the fountain particles concept. Finally, through a temporal and spatial microphysical study, coalescence below the $0{ }^{\circ} \mathrm{C}$ level, riming and freezing above, are concluded to be the major processes in the formation of intense precipitation. The essential role of ice phase in the formation and enhancement of precipitation has been highlighted.

KeYWORDs: Mesoscale Alpine Programme Orographic precipitating systems Polarimetry Radar observations

\section{INTRODUCTION}

The purpose of this paper is to investigate the dynamical and microphysical evolution of orographic precipitating systems, using Doppler and polarimetric data obtained during the Intensive Observation Period (IOP) 3 (24-26 September) of the Mesoscale Alpine Programme (MAP: Bougeault et al. 1998, 2001; Binder et al. 1999). MAP was conducted in the Alps during the autumn of the year 1999 in order to understand the effects of the orography on atmospheric phenomena, in particular the microphysical growth processes of precipitation in the dedicated wet MAP component. As shown by Frei and Schaer (1998) through a statistical study from 1971 to 1990 , the Lago Maggiore region, which is considered in the present paper, is characterized, in autumn, by a precipitation maximum. Besides, as reported by the MAP Science Director's Notes and the POC (Project Operations Center) Science Director's Notes (website http://www.joss.ucar/edu/map/catalog/), precipitation accumulation in IOP3 reached $400 \mathrm{~mm}$. For comparison, IOP2b (19-21 September) which was extensively studied (see hereafter) was characterized by precipitation accumulation of about $200 \mathrm{~mm}$ locally (Georgis et al. 2003; Medina and Houze 2003a).

\footnotetext{
* Corresponding author: Laboratoire d'aérologie, Observatoire Midi-Pyrénées, 14, avenue Edouard Belin, 31400 Toulouse, France. e-mail: pujo@aero.obs-mip.fr
} 
In this paper, we attempt to identify the microphysical and physical processes involved in the generation of intense precipitation and the conditions (orographic, thermodynamic , . . ) favourable for their triggering. Two types of microphysical mechanism are generally distinguished: stratiform mechanisms, occurring in weak vertical motions so that hydrometeor growth is limited, and convective mechanisms occurring in updraughts strong enough to carry hydrometeors aloft. In the first case, ice crystals form and grow by water vapour deposition, then fall and melt, leading to rain when falling through the $0{ }^{\circ} \mathrm{C}$ level. In the second case, strong updraughts and high liquid water content favour accretion phenomena like coalescence (droplets and drops collision increasing drop size), aggregation (ice crystals collisions resulting in snow formation), riming (supercooled drops and ice crystals collision leading to graupel formation) and freezing (water liquid/ice transformation). Houghton (1968) first considered these convective mechanisms as very efficient in intense precipitation formation. Naturally, these mechanisms are not exclusive: they can coexist and, generally, a convective part is embedded in a stratiform background and tends to become stratiform (Yuter and Houze 1995; Houze 1997).

In the context of orographic precipitation, the question which naturally emerges is how, for given synoptic and thermodynamic conditions, mountains can act to favour these different processes. During the MAP experiment, a typical example of stratiform orographic precipitation was IOP8 (Pradier et al. 2004). According to dynamical and thermodynamic studies (Rotunno and Ferretti 2003; Bousquet and Smull 2003; Medina and Houze 2003a), it was characterized by stable cold air, close to saturation with a low Froude number $(F r<1$, meaning that air does not easily pass over mountains), which favoured upstream blocking by the first mountain slopes. For such a situation Medina and Houze (2003a) elaborated a conceptual model for the microphysics. According to these authors, only low-level flow (below $1 \mathrm{~km}$ altitude) is blocked; the drier layers above could be smoothly lifted by the mountain. During the ascent, ice crystals and dry snow would be formed by deposition, and then melt through the $0{ }^{\circ} \mathrm{C}$ level resulting in rain below.

As suggested by Smith (1979), orographic effects on the airflow can favour the generation of very active convective cells. During MAP, IOP 2b, 3 and 5 (2-5 October) provide three examples of such situations. As shown by Medina and Houze (2003b), strong similarities can be observed between these three cases, especially between IOP $2 b$ and IOP3. IOP2b, which corresponds to warm and very moist, potentially unstable air with a high Froude number ( $\mathrm{Fr}>1$, meaning that air can easily pass over mountains) is probably the most characteristic one. In order to explain the intensity of these processes, Medina and Houze (2003a) suggest a microphysical conceptual model based on:

- $\quad$ Lifting of the moist low-level layer;

- Release of potential instability, during the orographic lifting on the windward slope of the first mountain, resulting in the generation of active convective cells.

Strong updraughts and high liquid water content inside the cells would promote coalescence of droplets and drops below $0{ }^{\circ} \mathrm{C}$, riming and freezing above leading to graupel formation. Melting of graupel during their fall through the $0{ }^{\circ} \mathrm{C}$ level would enhance precipitation. Yuter and Houze (2003), with the help of a one-dimensional (1D) model initially proposed by Kessler (1969), confirm the previous suggestions, and show that the greater the updraughts, the more intense the convective processes. They also emphasized the importance of the ice phase in the formation of precipitation since a simulation taking only into account the coalescence process provided lower precipitation rates than usually observed. 
Complementary studies on dynamics and thermodynamics by Georgis et al. (2003) and Medina and Houze (2003a) made IOP2b the most documented MAP case. But so far, no study has attempted a complete spatio-temporal investigation of both the microphysics and kinematics of orographic precipitation since all of them were limited to either mean or only 1D characteristics. The high resolution Doppler data collected during IOP3 by the French Ronsard, the Swiss Monte-Lema and the US NCAR (National Center for Atmospheric Research) SPOL ground-based radars in the Lago Maggiore region with the S-band polarimetric data provided by only SPOL, offer the opportunity to investigate the evolution of the 3D dynamical and microphysical characteristics relative to a convective orographic situation. Thus, the present work is expected not only to verify the main results obtained from the mean or 1D previous studies, but also to clear up the microphysical processes in the formation of precipitation in a mountainous region.

In section 2, the meteorological situation of the IOP3 is discussed through observations and model output. In section 3, we present the target area and the triple Doppler radar network and we briefly recall the data processing (wind, reflectivity and microphysics fields retrieval) with a particular attention to the fuzzy-logic algorithm used to classify hydrometeors from the polarimetric variables measured by SPOL. In the following section 4 , we discuss the results obtained from a statistical and temporal mean study of the system. In section 5, we present results obtained from a four-dimensional analysis of kinematics and microphysics. Finally, section 6 concludes with the growth mechanisms involved in the orographic precipitation observed during MAP IOP3 in the Lago Maggiore region.

\section{OVERVIEW OF THE IOP3}

\section{(a) Synoptic situation}

At 1200 UTC 25 September a trough was located north of Scotland with an axis extending to Morocco, which favoured a southwesterly flow over the Mediterranean Sea, Spain, France and northern Italy (Fig. 1). According to the European Centre for Medium-Range Weather Forecasts (ECMWF), a south-westerly flow towards the Alps due to the slow eastward motion of the trough is expected at 2400 UTC (not shown). It should be noted that this synoptic situation is favourable to heavy precipitation south of the Alps, as shown by Massacand et al. (1998) through an analysis of the meteorological conditions propitious to flooding in Alpine regions.

Figure 2 displays the wind field, forecasted at $10 \mathrm{~m}$ altitude for 1200 UTC 25 September by the Swiss Model (SM) initialized at 0000 UTC; the area considered in the present work is represented by the black square. It shows a southerly flow toward the Alps. Conditions are then favourable for the advection of moist air from the Mediterranean Sea to the Alps, and orographic precipitation can be expected on the southern slopes of the Alps. This is confirmed by the infrared satellite image of Meteosat at $1800^{*}$ UTC, displayed in Fig. 3, which shows a precipitating system oriented southwest-northeast from northern Africa to Russia and passing over Spain, France and northern Italy, in particular over the so-called Lago Maggiore Target Area (LMTA, represented by the inner small box). Moreover, the Mesoscale Compressible Community numerical model (MC2) initialized at 0000 UTC forecasted the strongest precipitation between 1600 UTC and 1900 UTC over LMTA. It also indicates a south-westerly flow at $850 \mathrm{hPa}$ toward the Alps which becomes a southerly flow over the Lago Maggiore region (not shown).

\footnotetext{
* A sequence of this type of image (not shown) is available on the website http://www.map.ethz.ch
} 


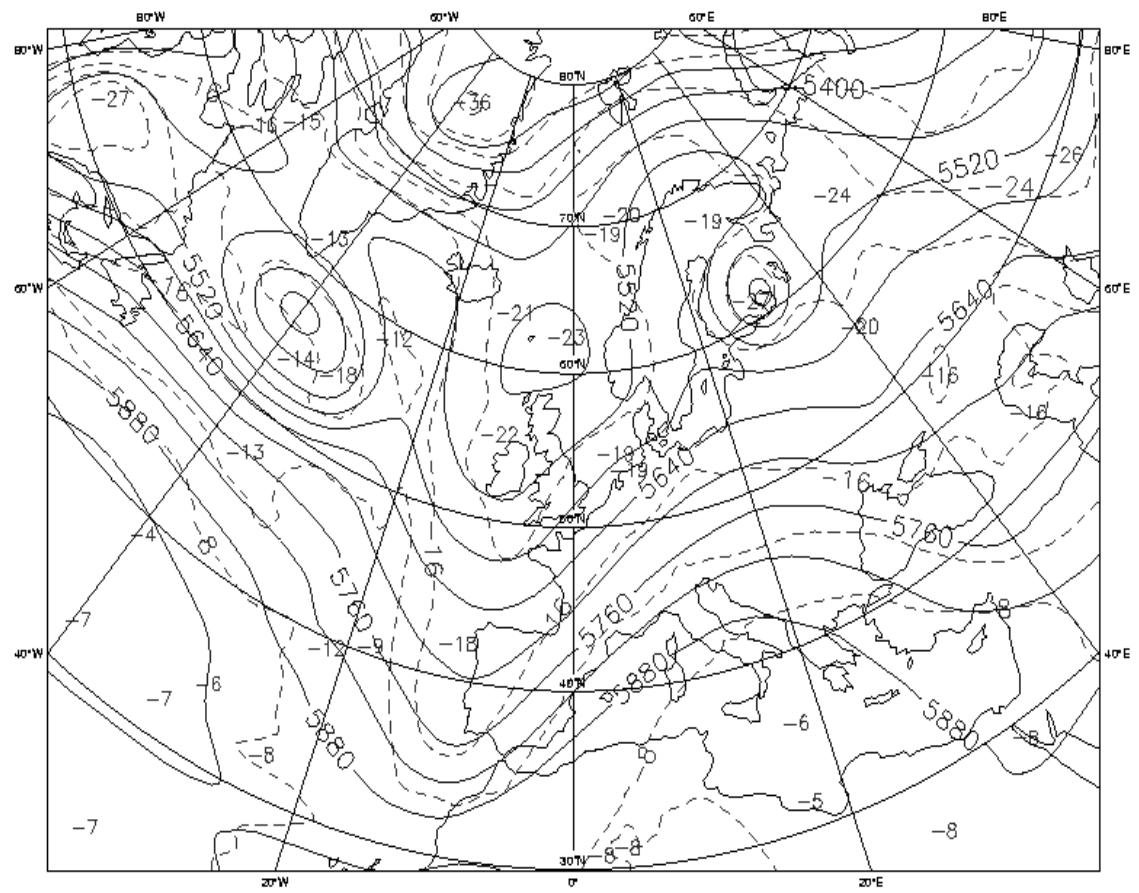

Figure 1. $500 \mathrm{hPa}$ geopotential height (continuous lines every $60 \mathrm{~m}$ ) and temperature (dashed lines every $4{ }^{\circ} \mathrm{C}$ ) on 25 September 1999 at 1200 UTC from the European Centre for Medium-Range Weather Forecasts.

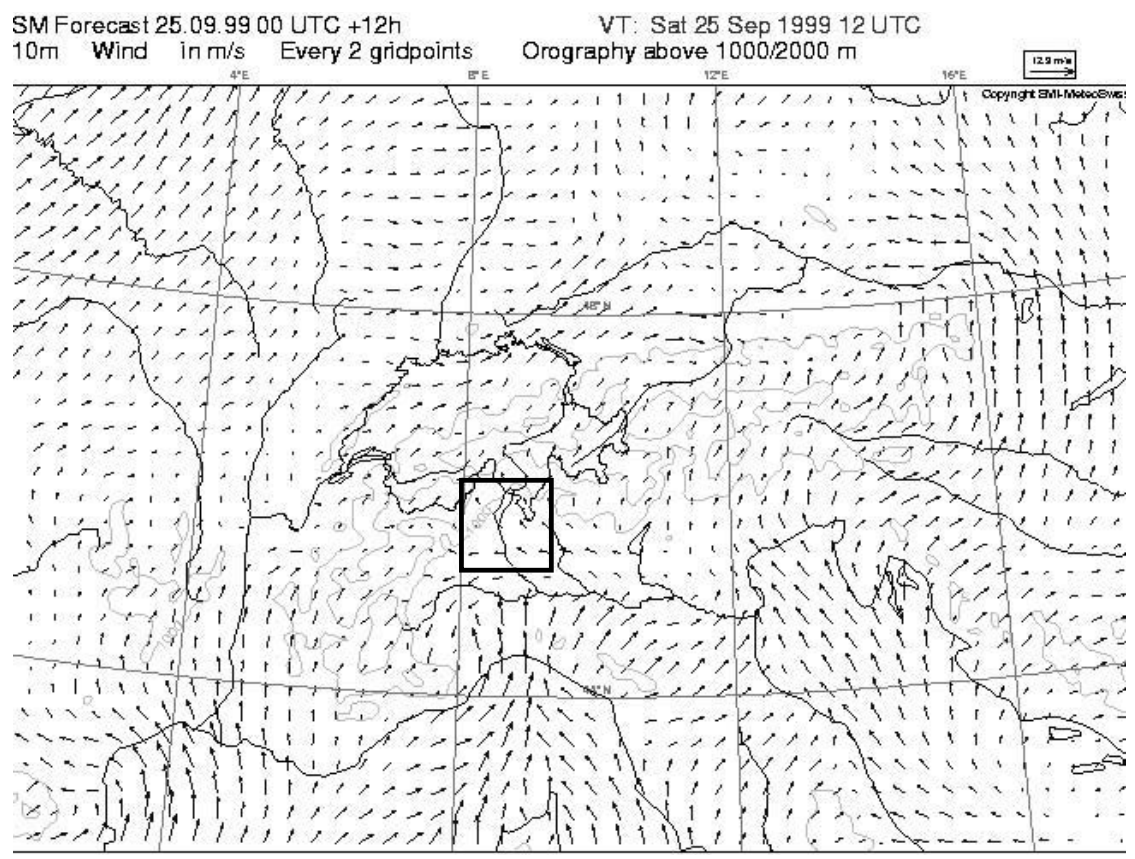

Figure 2. Wind at $10 \mathrm{~m}$ altitude over the Alpine regions on 25 September at 1200 UTC from the Swiss Model. The square box corresponds to the Lago Maggiore region. 


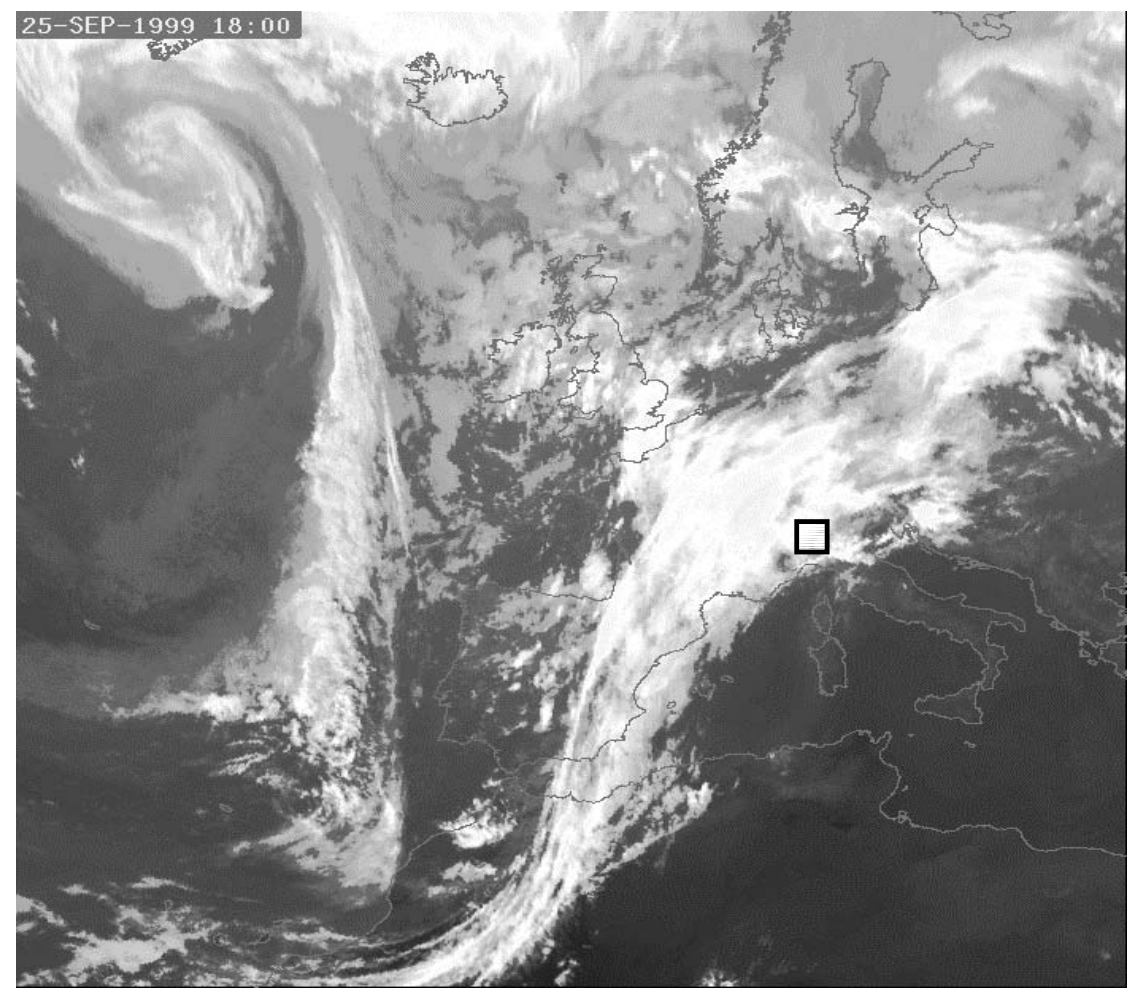

Figure 3. Infrared image of Meteosat on 25 September at 1800 UTC. It shows a precipitating system extending from north Africa to Russia and passing over the Lago Maggiore region (black square).

(b) Thermodynamics of the airflow

Figure 4 shows the Milan/Linate radiosounding at 1200 UTC which can be considered as representative of the precipitation occurring at the end of the afternoon (17202000 UTC) in the Lago Maggiore target area since thermodynamic conditions do not significantly change during the afternoon as confirmed by the radiosounding at 1800 UTC (not shown).

This radiosounding indicates very moist air with relative humidity increasing from $70 \%$ at the ground to $100 \%$ at $600 \mathrm{hPa}$, above which a thin layer of temperature inversion is observed. Aloft, the atmosphere is drier with a minimum relative humidity (about $40 \%$ ) at $550 \mathrm{hPa}$. Surface temperature is $20{ }^{\circ} \mathrm{C}$ and the $0{ }^{\circ} \mathrm{C}$ isotherm is at about $630 \mathrm{hPa}$. The atmosphere is convectively unstable with a separation of only $400 \mathrm{~m}$ between the lifting condensation level (LCL) and the level of free convection (LFC), respectively located at about $930 \mathrm{hPa}(700 \mathrm{~m})$ and $880 \mathrm{hPa}(1100 \mathrm{~m})$. However, the temperature inversion strongly limits the unstable character. The convective inhibition (CIN) is about $20 \mathrm{~J} \mathrm{~kg}^{-1}$ while the convective available potential energy (CAPE) is only about $500 \mathrm{~J} \mathrm{~kg}^{-1}$. These values are similar to those found for IOP2b (Georgis et al. 2003).

\section{DOPPLER AND POLARIMETRIC DATA ANALYSES}

The horizontal domain of $150 \mathrm{~km}$ square centred on $\left(45.70^{\circ} \mathrm{N}, 8.60^{\circ} \mathrm{E}\right)$ displayed in Fig. 5(a) encompasses different terrains, with the flat Po Valley to the south, 


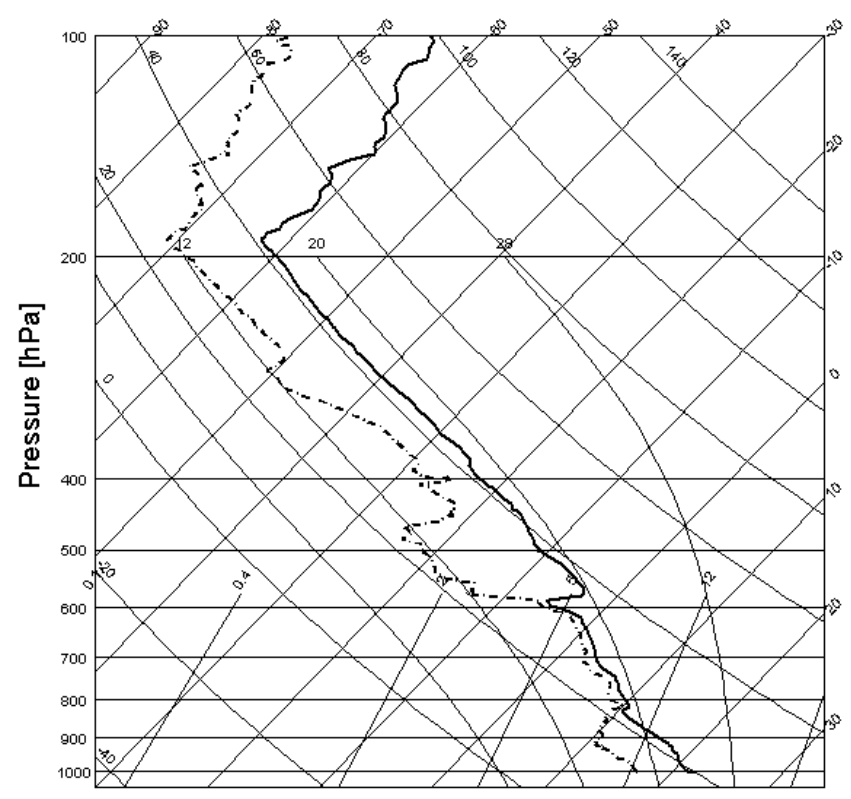

Figure 4. Skew T-log p diagram from radiosoundings launched at Milan/Linate on 25 September 1999 at 1200 UTC. Continuous and dotted lines relate to air and dew point temperature (in ${ }^{\circ} \mathrm{C}$ ) respectively.

the hilly Piedmont to the south-west, the high Alpine mountains to the north with Lago Maggiore and the deep Toce and Ticino Valleys. It corresponds to the maximum area within the LMTA, over which reliable information about kinematics and microphysics can be obtained every 15 minutes from observations conducted during MAP IOP3 with the French Ronsard Doppler radar, the Swiss Meteorological Agency Doppler radar at Monte Lema and the US SPOL polarimetric Doppler radar. The main characteristics of these ground-based radars are presented in appendix A. The inner box in Fig. 5(a) defines the subdomain used in this study to investigate the precipitation occurring during IOP3. It is a $80 \mathrm{~km}$ square domain centred at $\left(46.10^{\circ} \mathrm{N}, 8.75^{\circ} \mathrm{E}\right)$ and details of the topographic features are displayed in Fig. 5(b). In order to investigate the detailed kinematics and microphysical structure of the IOP3 rain event over this region, Doppler and polarimetric observations have been interpolated onto a Cartesian grid with horizontal and vertical grid spacing of $1 \mathrm{~km}$ and $0.5 \mathrm{~km}$, respectively. Since no significant radar signal was detected above $10 \mathrm{~km}$ altitude, the domain in which the retrieval of the 3D kinematic and microphysical fields is done consists of a box of $80 \times 80 \times 20=128000$ grid points. Each point of the grid is located by its Cartesian coordinates $x, y$ and $z$ in the west-east, south-north and vertical direction, respectively.

Doppler data have been analysed using the real-time and automated multipleDoppler analysis method (RAMDAM) described in Chong et al. (2000) and already successfully applied on numerous MAP cases (IOP5 by Pradier et al. 2002, IOP2b by Georgis et al. 2003, IOPs 4, 8, 9 and 15 by Pradier et al. 2004). This technique permits the retrieval of reliable 3D wind fields over a complex orography. On the other hand, since the radar signal illuminates a cloud volume often containing a hydrometeor mixture and because of experimental uncertainties, the identification of a given hydrometeor class (HC) from polarimetric variables (POV) measured by SPOL (see appendix B) is based on a probabilistic method (fuzzy logic method) theoretically developed by Mendel (1995) and Bringi and Chandrasekar (2001). Such a method has been applied by 
(a)

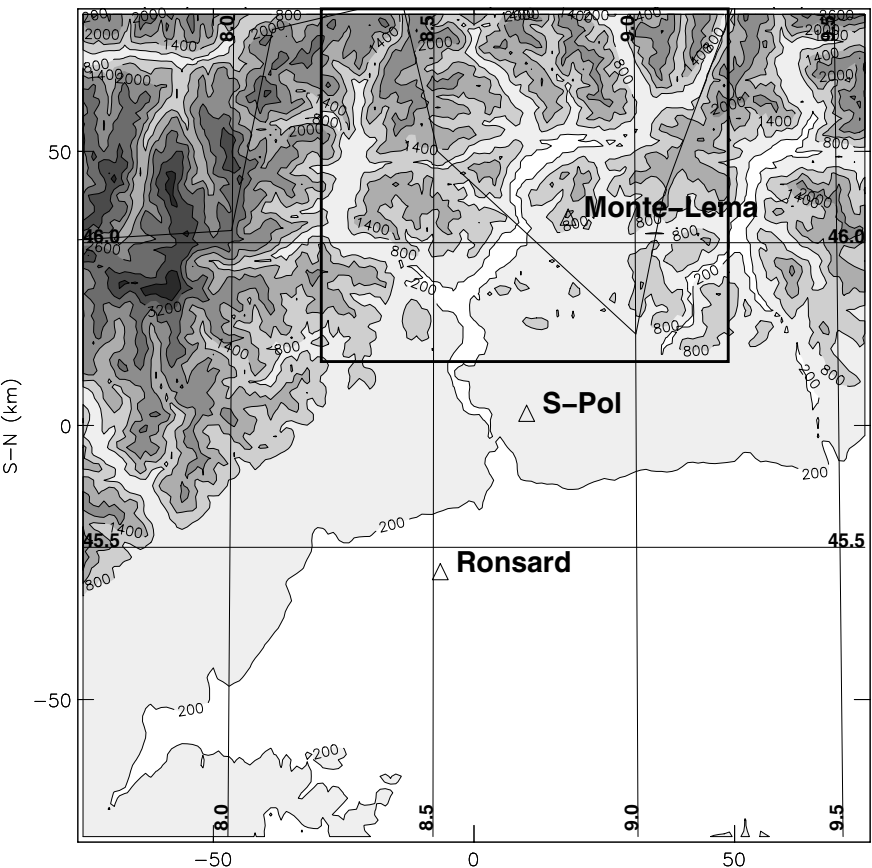

(b)

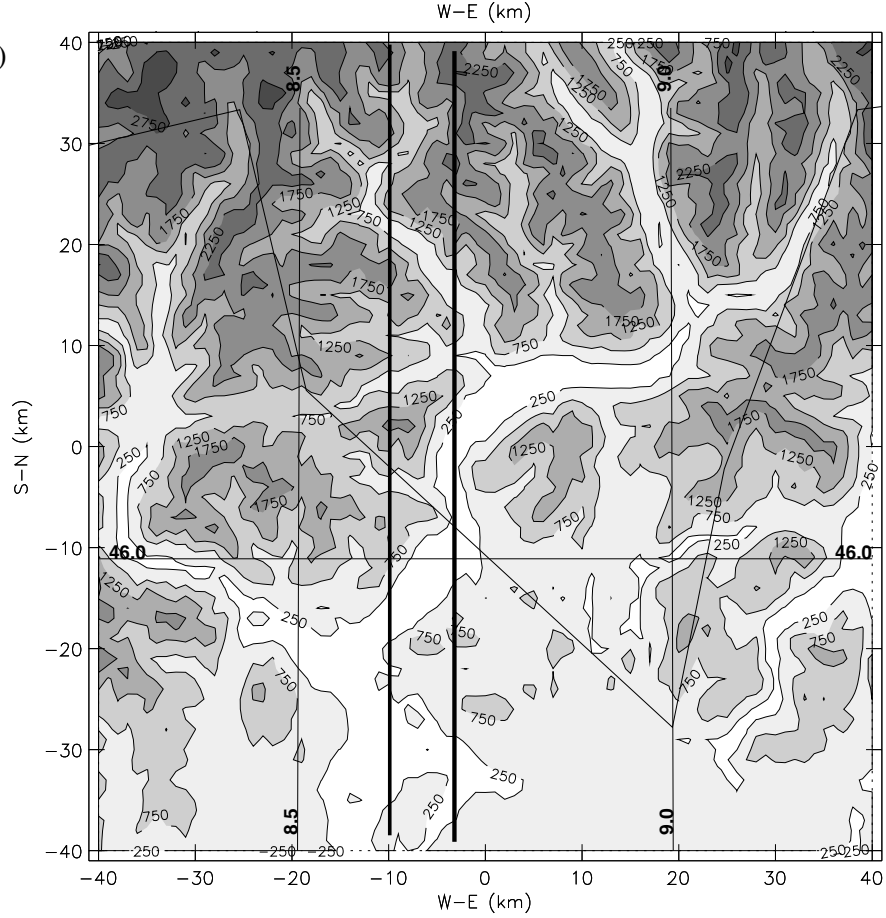

Figure 5. (a) Triple Doppler radar network and underlying terrain in the Lago Maggiore region during MAP (contours every $600 \mathrm{~m}$ ). (b) Domain of Doppler-derived wind and precipitation (contours every $500 \mathrm{~m}$ ). 
Vivekanandan et al. (1999) (NCAR algorithm) to discriminate the hydrometeors inside a radar-observed precipitating system using measured POV and temperature profile. The determination of the $0{ }^{\circ} \mathrm{C}$ level from radiosoundings is important to avoid ambiguous results such as ice particles in areas of positive temperature. In the NCAR algorithm, each $\mathrm{HC}$ is associated with a specific probability function $P$, depending on POV, which indicates the accuracy of the particle identification from the measured value of the POV. These functions are obtained from numerical studies and observations. Usual forms are the rectangle or trapezoidal functions of unit height and variable base defined by the extreme values that a POV takes for a given hydrometeor. Each of them is then multiplied by a weight factor $W$ determined according to experimental and subjective criteria (such as the relevance of the POV and the accuracy of its measurement). Then, for each HC the weighted functions relative to the observed POVs are summed up to obtain a unique parameter:

$$
Q=\sum W P .
$$

The HC corresponding to the strongest value of $Q$ is the result of the identification procedure. It is to be noted that the weight $W$ attributed to $Z_{\mathrm{h}}, Z D R$ (definition in appendix B) and temperature is double due to the accuracy in their measurements (Vivekanandan et al. 1999).

In the present study, the NCAR algorithm is used with the radiosounding launched at Milan/Linate at 1200 UTC 25 September, supposing that the $0{ }^{\circ} \mathrm{C}$ level is unchanged within the whole considered domain (i.e. $3.5 \mathrm{~km}$ altitude according to Fig. 4). Nine classes are then identified: light rain (LR), medium rain (MR), heavy rain (HR), hail (HA), rain-hail mixture (RH), graupel-hail mixture (GH), wet snow (WS), dry snow (DS) and ice crystals (IC).

\section{STATISTICAL AND TEMPORAL MEAN CHARACTERISTICS}

\section{(a) Statistical analysis}

In order to highlight the most intense microphysical activity, a statistical study of the system is realized between 1559 UTC and 2031 UTC. It consists of counting on the Cartesian grid (defined in section 3), relative to the considered domain (Fig. 5(b)), the number of points (NP) associated with a given $\mathrm{HC}$ at each observation time. In order to eliminate the low-precipitating stratiform structure, only grid points characterized by a reflectivity greater than or equal to $20 \mathrm{dBZ}$ are taken into account in the statistics. Obviously, because they depend on the grid characteristics, these numbers have relative but not intrinsic values.

Figure 6 shows that light rain (LR) and, to a lesser extent, dry snow (DS) are dominant within the considered precipitation volume. It is to be noted that LR is maximum at around 1920 UTC whereas all the other observed hydrometeors are maximum before, i.e. at around 1840 UTC. Nevertheless, for all the HCs, the associated NP rapidly increases from 1750 UTC until the time corresponding to the maximum, then decreases as quickly. This suggests the occurrence of very efficient microphysical and physical processes, like coalescence, riming or freezing. Next, we will focus on the period including both the active and dissipative phases, i.e. from 1720 UTC to 1950 UTC. The next two subsections (b) and (c) concern the temporal mean study of the system over this period. 


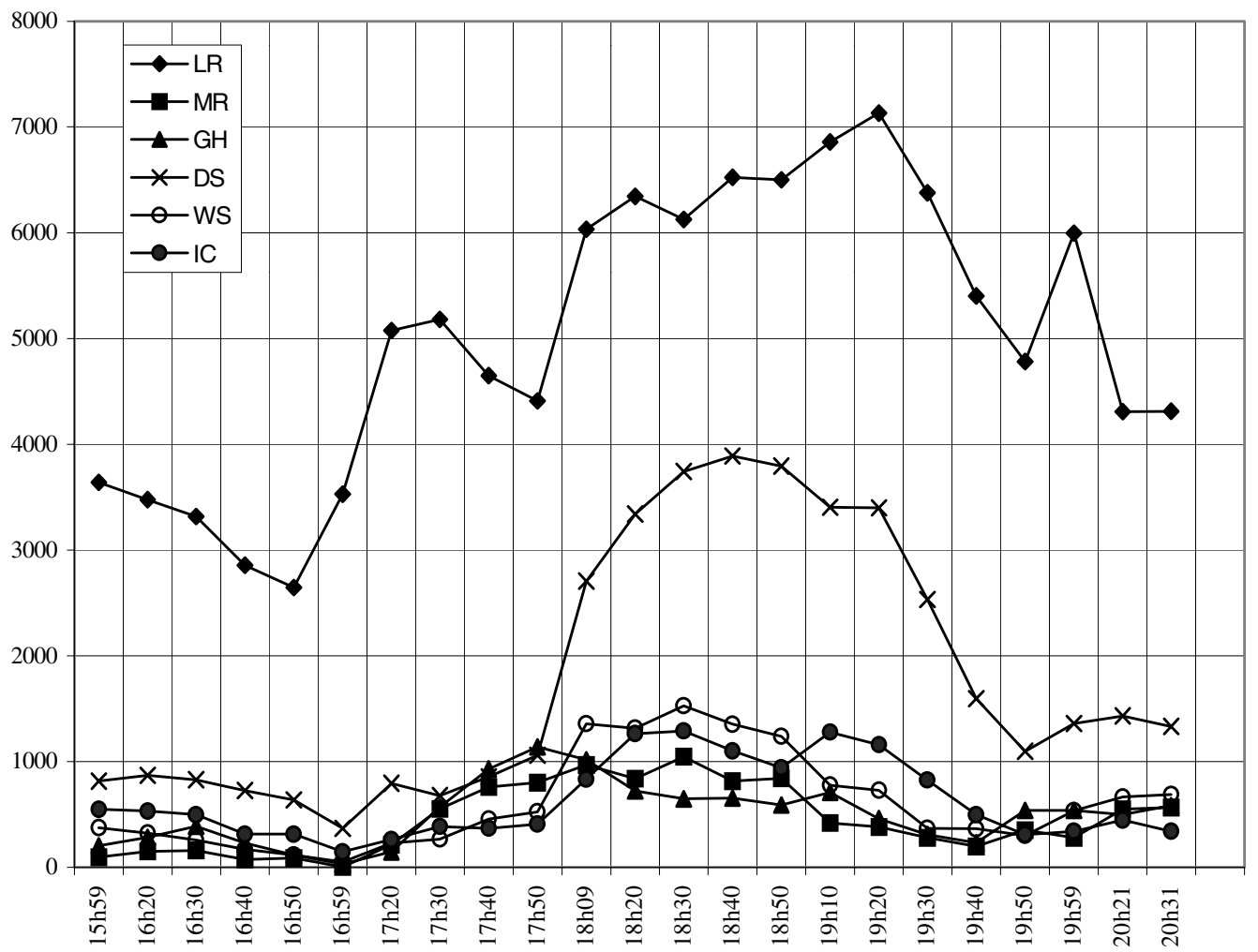

Figure 6. Plot of the grid-point number associated with a given $\mathrm{HC}$ versus time.

\section{(b) Temporal mean reflectivity and wind field pattern}

In order to emphasize the main characteristics of the dynamics and the precipitation, the airflow and reflectivity are averaged between 1720 UTC and 1950 UTC at each grid point of the studied domain to obtain a mean 3D wind and precipitation field*.

(i) Horizontal cross sections. An examination of various horizontal cross sections of reflectivity reveals that precipitation becomes insignificant above $4 \mathrm{~km}$ altitude. Concerning the mean wind field, the general flow is southerly below $3 \mathrm{~km}$ and southwesterly above with a zonal component increasing with altitude and no major modification of the meridional component. This apparent counterclockwise rotation of the flow from top to surface can be explained by the channelling of the low-level flow through the gap between the Maritime Alps and the Apennines. Figure 7(a) shows the mean reflectivity signal with superimposed horizontal wind field at an altitude of $3 \mathrm{~km}$. This altitude is low enough to avoid low quasi-uniform reflectivity values characteristic of ice phases, and high enough to limit ground echoes. The reflectivity core is about $34 \mathrm{dBZ}$ and is primarily located over Lago Maggiore and the foothills of the Alpine mountains. The temporal mean direction of the wind is southwesterly with a dominant southerly component toward the Lago Maggiore area which urges us to analyse meridional cross sections.

\footnotetext{
* The averaging of the reflectivity was done in linear space.
} 
(a)

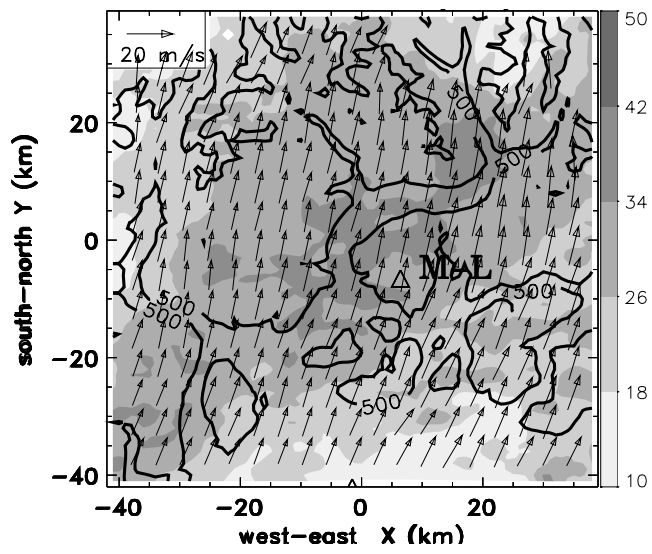

(b)

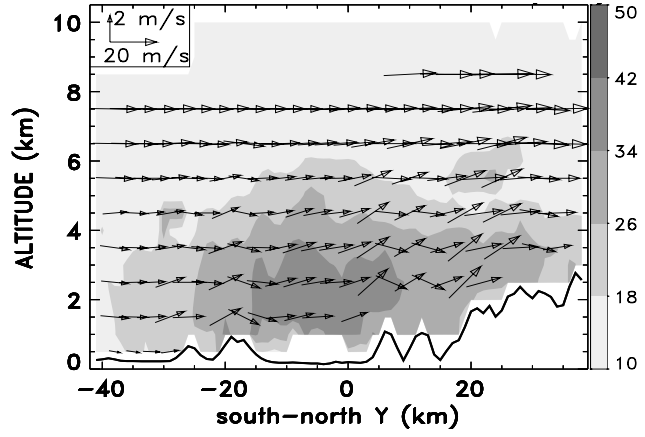

(c)

(d)
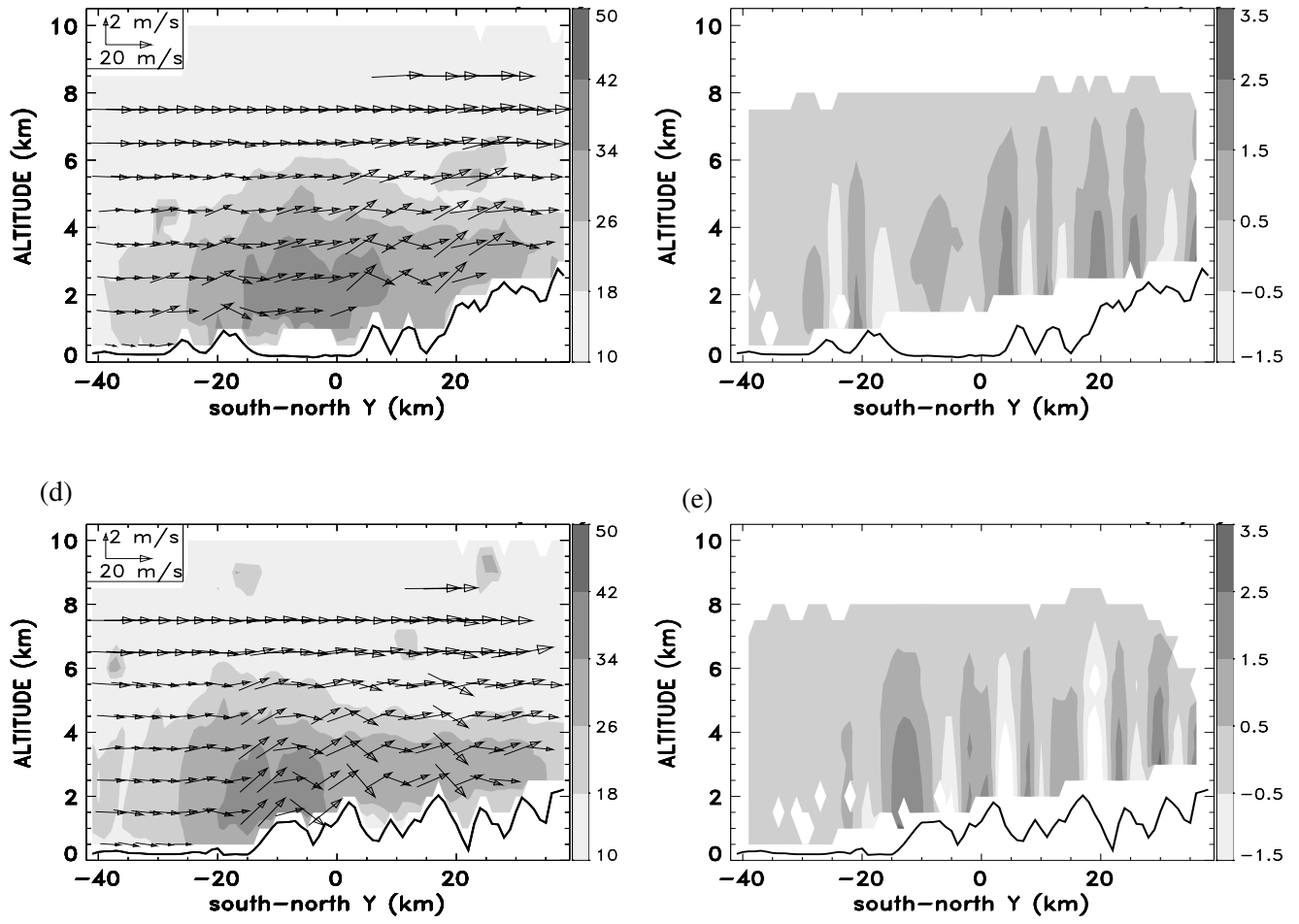

(e)

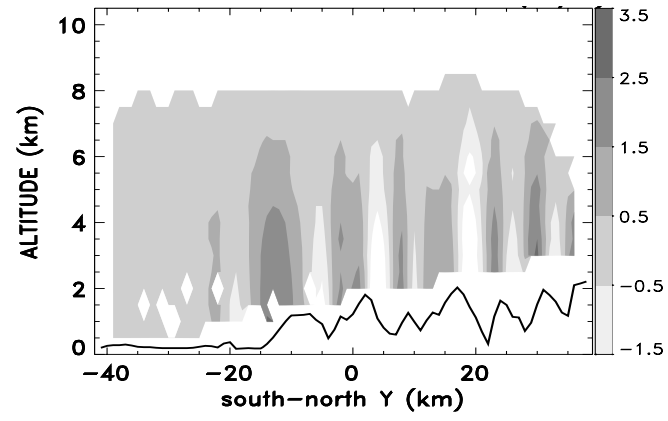

Figure 7. (a) Mean reflectivity values and wind vectors (reference vectors in upper left corner) with superimposed topographic contour at $500 \mathrm{~m}$ altitude over the 1720-1950 UTC period for the horizontal cross section at $3 \mathrm{~km}$ altitude. (b) and (d) are meridional cross sections through the mean 3D retrieval wind and reflectivity fields at $x=-3 \mathrm{~km}$ and $x=-10 \mathrm{~km}$ respectively. (c) and (e) as (b) and (d), respectively, but for mean vertical air velocity. Reflectivity and wind velocity are expressed in $\mathrm{dBZ}$ and $\mathrm{m} \mathrm{s}^{-1}$ respectively. 
(ii) Meridional cross sections: $x=-3 \mathrm{~km}$ and $x=-10 \mathrm{~km}$. Both have been chosen to intersect high reflectivity cells like for example those at $(x ; y)=(-3 ;-10)$ and $(-10 ;-15)$ at 1750 UTC (see Fig. 9(b)). The $x=-3 \mathrm{~km}$ cross-section (Figs. 7(b)(c)) depicts a highly variable topography with an alternation of flat and rough terrains. The regions $y=-40$ to $-30 \mathrm{~km}$ and $y=-15$ to $3 \mathrm{~km}$ correspond to Lago Maggiore. The second one at $x=-10 \mathrm{~km}$ (Figs. 7(d)-(e)) has a more marked transition between the lake $(-35 \mathrm{~km}<y<-15 \mathrm{~km})$ and the Alps, which are characterized by a succession of peaks and valleys at $y>-15 \mathrm{~km}$.

It is well known that moisture can be injected into the atmosphere by evaporation from local sources, such as lakes, marshes or even regions where it has recently rained, in enough quantity to favour thunderstorm development even in cases where moisture imported from great distances by large-scale wind systems is inadequate (Banta 1990). Already at the beginning of the eighties, Cotton et al. (1982) and Raymond and Wilkening (1982) emphasized the importance of local sources of moisture in deep moist convection. Then, Segal et al. (1989) demonstrated that the irrigation in eastern Colorado can produce local thermally forced circulations. Finally, the Lake-Induced Convection Experiment and the Snowband Dynamics project (Kristovich et al. 2000) was the first opportunity to investigate the processes that locally enhance precipitation near the Great Lakes by as much as $300 \%$ (per year) compared to regions outside their influence (Scott and Huff 1996). Air flowing over the relatively warm surfaces of the Great Lakes is responsible for this situation. Since Lago Maggiore remains still relatively warm during the autumn, it is not unlikely that, to some extent, it also favours intense evaporation and, therefore, the production of convective instability.

On the other hand, Garrett (1982) showed that not only the soil moisture but also the vegetative cover and the roughness affect the location of convective cells, which was later confirmed by Mahfouf et al. (1987) through a numerical study. More precisely, Chang and Wetzel (1991) showed that the evolution of the pre-storm convective environment in the High Plains depends greatly on spatial variations in vegetation and soil moisture. Sensitivity of moist convection to landscape variability in a mountainous region was also highlighted by Chen et al. (2001). This is why the two considered meridional cross-sections are expected to provide information on the influence of the surface on the development and/or the evolution of precipitation. In particular they are likely to emphasize the distinct role of the lake and the mountain in the processes involved in the initiation and/or the enhancement of the observed precipitation.

Along $x=-3 \mathrm{~km}$ (Fig. 7(b)), a high-reflectivity cell (34 dBZ) is observed over the lake between $1 \mathrm{~km}$ and $3.5 \mathrm{~km}$ altitude, upwind of the mountains, which suggests that the lake could be a local moisture source. Nevertheless, a comparison between Fig. 7(b) and Fig. 7(c) shows that cells do not develop systematically over the lake since they are not associated with the strongest mean updraughts: convection can also begin earlier over the first mountains, then be advected by the steering flow. The location of the reflectivity maximum (between $1 \mathrm{~km}$ and $3.5 \mathrm{~km}$ altitude) is suggestive of coalescence processes at low level as proposed by Medina and Houze (2003a). Along $x=-10 \mathrm{~km}$ (Fig. 7(d)), a more classical structure of upslope convection can be observed: a cell of mean reflectivity equal to $34 \mathrm{dBZ}$ is located just over the first mountain and associated with the main updraught core as displayed in Fig. 7(e), although orographically induced updraughts are observed above the subsequent peaks.

In general, these results are similar to those from IOP2b by Medina and Houze (2003a) and Georgis et al. (2003), who show a convective structure associated with a high mean reflectivity over the first peak. 

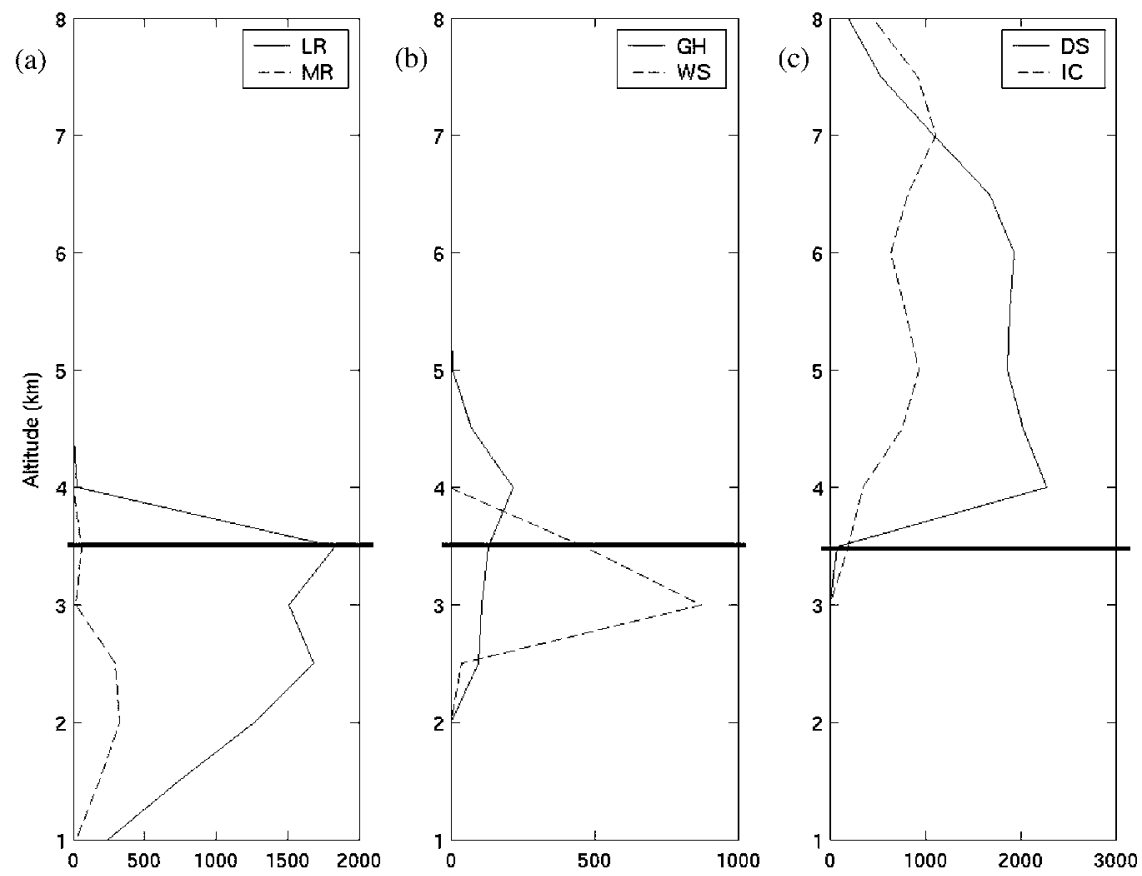

Figure 8. Vertical distribution of the mean number of grid points associated with each HC over the period $1720-$ 1950 UTC: (a) liquid hydrometeors, (b) melt hydrometeors, (c) iced hydrometeors. The $0{ }^{\circ} \mathrm{C}$ level (about $3.5 \mathrm{~km}$ altitude) is represented by a continuous black line in each graph.

\section{(c) Microphysical mean pattern versus altitude}

Figure 8 displays the temporal mean vertical distribution of the observed hydrometeors, i.e. the mean number of grid points associated with a given $\mathrm{HC}$, between 1720 UTC and 1950 UTC over the whole target area and above $1 \mathrm{~km}$ altitude because of the mask effect due to mountains. Figures 8(a), 8(b) and 8(c) are relative to the HC mainly present below (LR, MR), near (GH, WS) and above (IC, DS) the $0{ }^{\circ} \mathrm{C}$ level respectively. According to these panels, the mean vertical distribution of precipitation can be divided into three main superposed layers. In the first one, below $2.5 \mathrm{~km}$ altitude, only rain is observed with dominant LR. However, the greater part of LR concerns the upper layer between $2.5 \mathrm{~km}$ and $4 \mathrm{~km}$ altitude which contains the totality of WS and nearly the whole of GH. This organization characterized by a maximum of LR overhanging MR is consistent with coalescence which occurs at positive temperature at low level. Above $4 \mathrm{~km}$ altitude, the third layer contains the totality of iced particles with dominant DS. The relative quantity of each $\mathrm{HC}$ shows that rain can result not only from coalescence but also from iced particles melt and to a lesser extent from WS and GH melt. The presence of $\mathrm{GH}$ with a maximum at $4 \mathrm{~km}$ altitude, between the layers of WS and DS, strongly suggests two microphysical processes occurring near the freezing level: formation of $\mathrm{GH}$ by riming above, and melting of $\mathrm{GH}$ during its fall through, the $0{ }^{\circ} \mathrm{C}$ level leading to WS and probably also to HR. These results are consistent with those obtained by Yuter and Houze (2003) who compared the efficiency of the different microphysical processes (coalescence, riming, freezing, accretion). Similar observations concerning the hydrometeor distribution are reported by Medina and Houze (2003a) for IOP2b. In particular, they also observed graupel just above the $0{ }^{\circ} \mathrm{C}$ level in a $2 \mathrm{~km}$ thick layer. 
Although the results displayed by Figs. 8(a), 8(b) and 8(c) seem quite trivial they confirm the reliability of the $\mathrm{HC}$ algorithm and the subsequent kinematic and microphysical analysis in section 5. Nevertheless, the presence of sporadic WS just above the $0{ }^{\circ} \mathrm{C}$ level in Fig. 8(b) is questionable. This may be a consequence of the fundamental but unavoidable hypothesis concerning the $0{ }^{\circ} \mathrm{C}$ level in the $\mathrm{HC}$ algorithm, since it is considered as unchanged within the whole considered domain during all the studied period (see section 3). But this may also really result from a transport by updraughts according to the fountain particles concept of Yuter and Houze as discussed in section 5(b).

\section{KINEMATIC AND MICROPHYSICAL TEMPORAL ANALYSIS}

(a) Reflectivity and wind field evolution

(i) Horizontal cross sections. The wind field is helpful in understanding kinematic and microphysical processes implied in the evolution of precipitation. In this section, the reflectivity and wind fields from 1720 UTC to 1950 UTC are analysed.

Since the general evolution of the system is independent of the altitude, we rely in our discussion only on a horizontal cross section at $3 \mathrm{~km}$ altitude (Fig. 9) as in section 3 . Figure 9 clearly emphasizes three stages in the evolution of the precipitating system over the LMTA subdomain.

First, from 1720 UTC to 1809 UTC (Figs. 9(a), (b) and (c)), the reflectivity field exhibits an elongated structure with several cells $(Z>34 \mathrm{dBZ})$ along a southwestnortheast direction $\left(53^{\circ}\right.$ from north). The cells are associated with a very large meridional wind component and a low zonal component, so that this structure is progressively advected toward the north-northeast. At the same time a band structure develops and intensifies due to the progressive merging of the initial isolated cells observed at 1720 UTC (Fig. 9(a)), which are constrained by the orography to extend north-eastwards over the eastern branch of the lake. It is to be noted that precipitation is localized over the foothills of the Alps and Lago Maggiore and is then channelled by the eastern branch of the lake. In a second stage, from 1809 UTC to 1830 UTC (Fig. 9(c) and (d)), the progress of the strip is perturbed by the mountains. This results in a horizontal expansion of the system associated with high reflectivity values which cannot be explained only by aggregation of cells initiated over the southern tip of Lago Maggiore, even if this mechanism really occurs as indicated by the motion at about $30 \mathrm{~km} \mathrm{~h}^{-1}$ of three cells from $(x=-15 ; y=-35),(x=-3 ; y=-30),(x=+3 ; y=-27)$ to $(x=-10 ; y=-25),(x=+3 ; y=-25),(x=+12 ; y=-25)$ between 1809 UTC and 1830 UTC, respectively. Other reasons relating to orographic effects and ejection of hydrometeors according to the fountain particle concept are proposed in the following paragraph and section 4(b)(ii) respectively. It is also to be noted that reflectivity is still high, with values locally greater than $42 \mathrm{dBZ}$ at $1820 \mathrm{UTC}$ (not shown). Finally, from 1830 UTC to 1950 UTC (Fig. 9(d), (e) and (f)), the system weakens and dissipates, while precipitation continues to be advected northward, towards the high relief.

(ii) Meridional cross sections at $x=-10 \mathrm{~km}$ and $x=-3 \mathrm{~km}$. Cellular dynamics and orographic influence on precipitation structure are discussed using meridional cross sections at $x=-10 \mathrm{~km}$ and $x=-3 \mathrm{~km}$ for the period $1720 \mathrm{UTC}-1850 \mathrm{UTC}$, i.e. until the beginning of the dissipating phase.

In the $x=-10 \mathrm{~km}$ cross section (Fig. 10), a major convective cell ( $Z>42 \mathrm{dBZ}$ ) quickly developed in about 30 minutes, from 1720 UTC (Fig. 10(a)) to 1750 UTC (Fig. 10(b)), over the upslope of the first peak. Its vertical extension associated with 
(a)

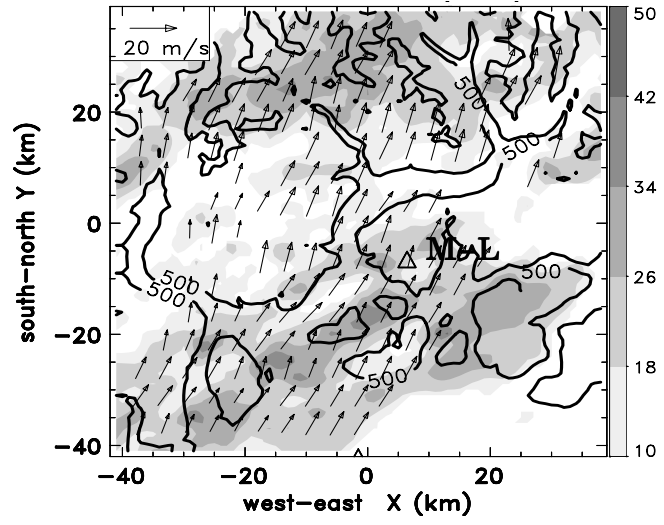

(c)

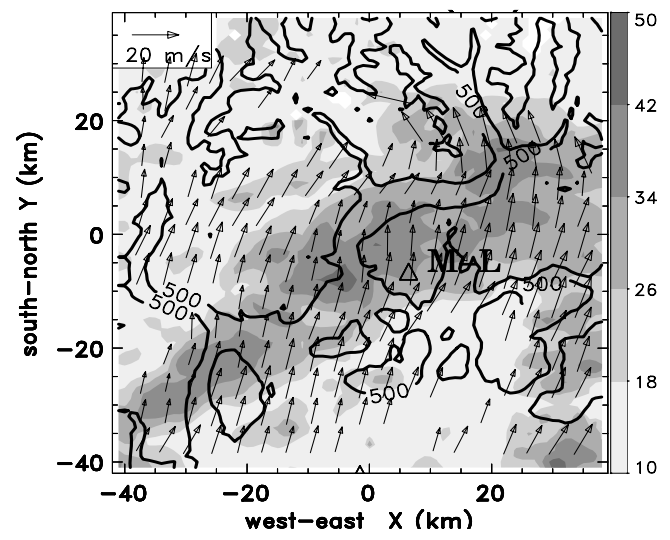

(e)

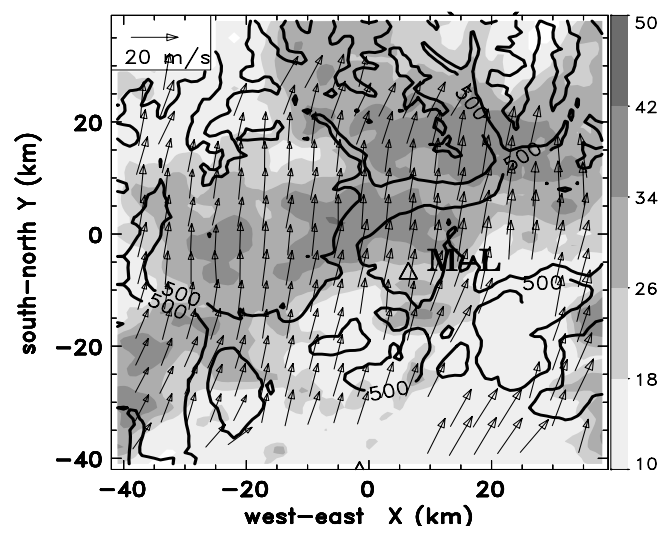

(b)

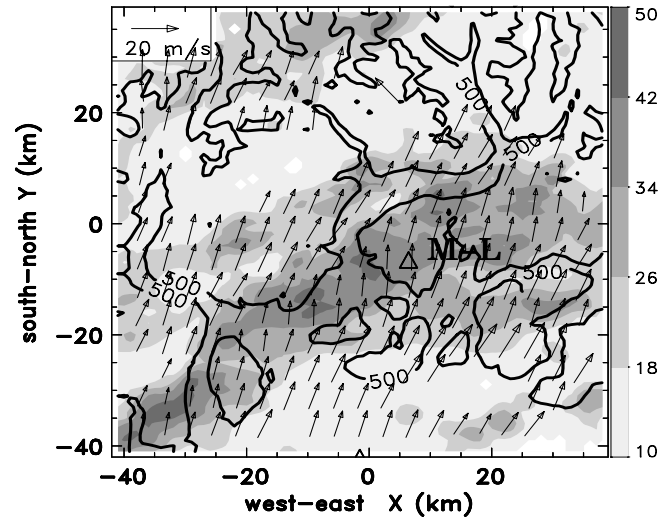

(d)

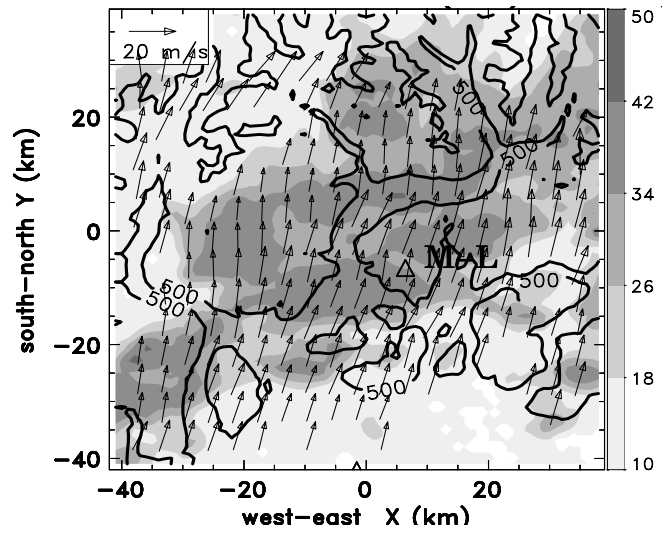

(f)

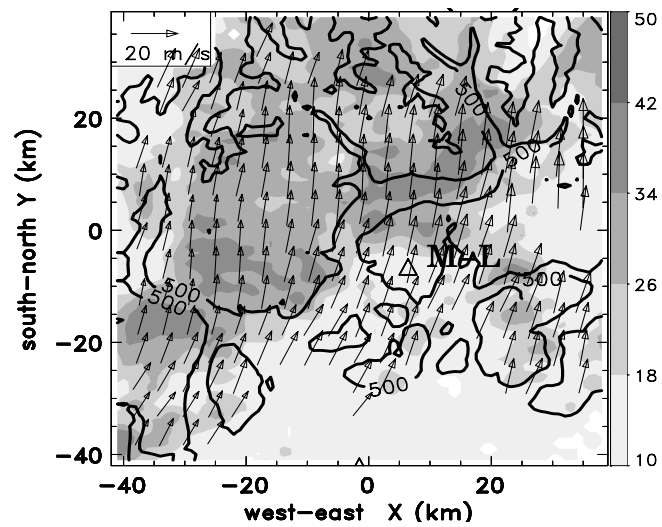

Figure 9. Horizontal cross sections in the Lago Maggiore region at $3 \mathrm{~km}$ altitude of wind vectors (reference vector in upper left corner, in $\mathrm{m} \mathrm{s}^{-1}$ ) retrieved through the RAMDAM method with superimposed radar reflectivity values (contours every $8 \mathrm{dBZ}$ ) and topographic contour at $500 \mathrm{~m}$ altitude at: (a) $1720 \mathrm{UTC}$, (b) $1750 \mathrm{UTC}$, (c) 1809 UTC, (d) 1830 UTC, (e) 1910 UTC and (f) 1950 UTC. 
(a)

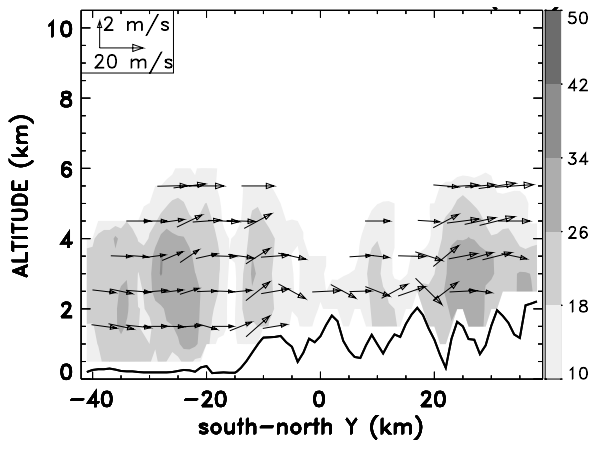

(c)

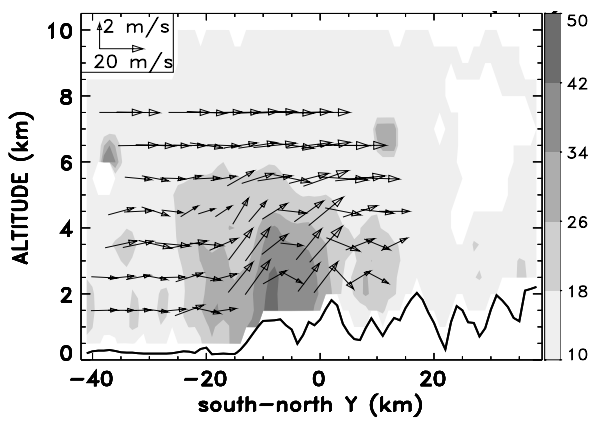

(e)

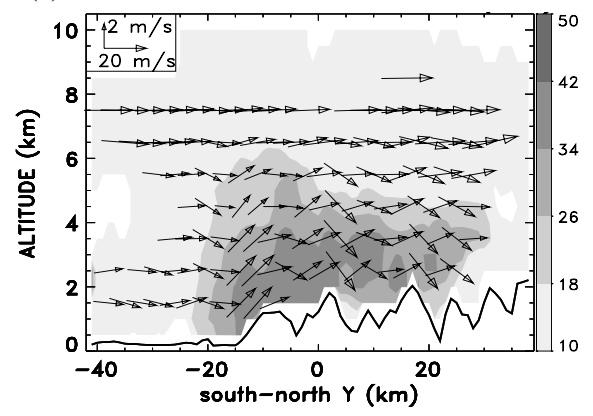

(b)

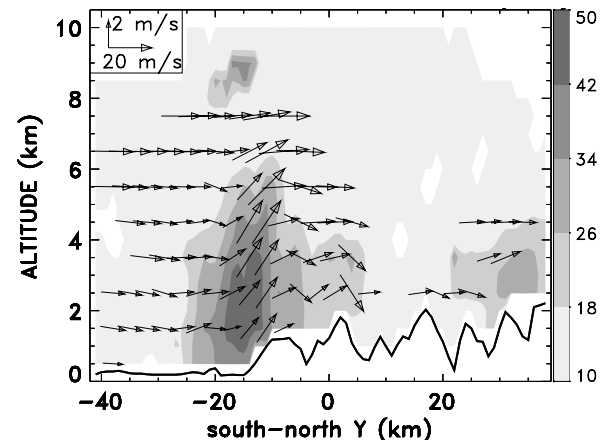

(d)

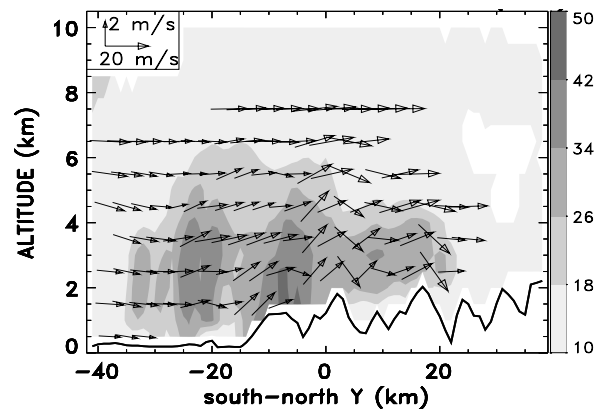

Figure 10. Vertical cross sections at $x=-10 \mathrm{~km}$ of wind vectors (reference vectors in upper left corner) with superimposed reflectivity values at (a) 1720 UTC, (b) 1750 UTC, (c) 1809 UTC, (d) 1820 UTC and (e) 1850 UTC. Reflectivity and wind velocity are expressed in $\mathrm{dBZ}$ and $\mathrm{m} \mathrm{s}^{-1}$ respectively.

a maximum of vertical air motion greater than $2.5 \mathrm{~m} \mathrm{~s}^{-1}$ at about $4 \mathrm{~km}$ above ground level (Fig. 11(a)) can be explained not only by orographic lifting but also probably by convective instability. At 1809 UTC (Figs. 10(c) and 11(b)) when the cell passes over the first mountain peak, the intensity of upward motions decreases, which leads to a lowering of the cell top, while a second upward motion develops over the upslope of the following peak. This second strong updraught (locally greater than $2.5 \mathrm{~m} \mathrm{~s}^{-1}$ ) may result from the orographic lifting of the downwind flow $\left(>1.5 \mathrm{~m} \mathrm{~s}^{-1}\right)$ associated with the precipitation occurring over the valley succeeding the first peak. The strong northward environmental flow aloft (greater than $20 \mathrm{~m} \mathrm{~s}^{-1}$ ) can also favour the advection of hydrometeors aloft beyond the second peak which can explain the maximum of reflectivity observed ten minutes later (Fig. 10(d)) around $3 \mathrm{~km}$ altitude, further into 
(a)

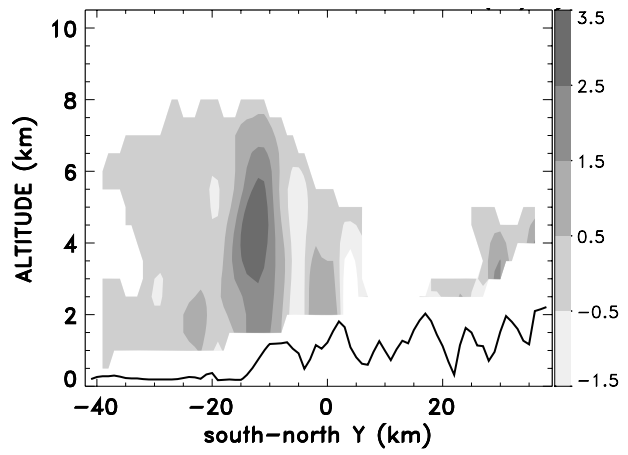

(c)

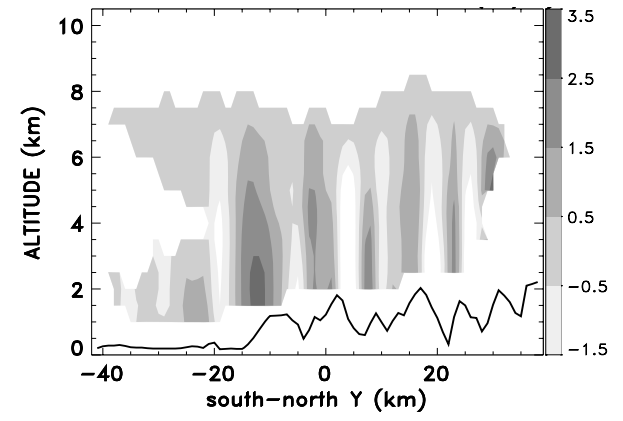

(b)

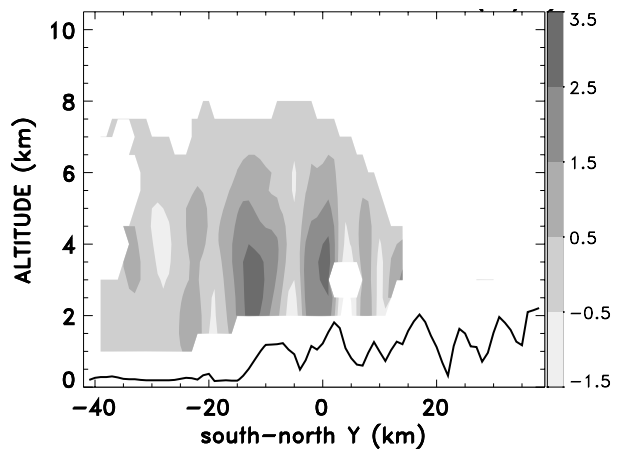

Figure 11. Vertical cross sections at $x=-10 \mathrm{~km}$ of vertical velocity at (a) $1750 \mathrm{UTC}$, (b) 1809 UTC and (c) 1850 UTC.

the Alpine chain (to the north). Repetition of such a process over the upslope of the following peak permits the system to progressively spread northwards (Fig. 10(e)). Of course, this spreading associated with high reflectivity values is made possible by a continuous feeding of the system by the strong updraught over the upslope of the first peak $(-15 \mathrm{~km}<y<-10 \mathrm{~km}$, Fig. 11(c)) where a maximum of precipitation is permanently observed. Besides, it is worth noting the development of precipitation over Lago Maggiore $(y<-15 \mathrm{~km}$ ) from 1809 UTC (Fig. 10(c)) to 1820 UTC (Fig. 10(d)) which can be explained by local convection and condensation of the southerly moist airflow. This suggests that Lago Maggiore can be considered as a local source of moisture. This feature is more emphasized on the $x=-3 \mathrm{~km}$ cross-section (Fig. 12).

According to Figs. 9(a) and 12(a), a cell develops at around 1720 UTC over an isolated massif at $y=-20 \mathrm{~km}$ (and $x=-3 \mathrm{~km}$ ); this cell extends vertically up to $z=5 \mathrm{~km}$ and moves progressively northwards over Lago Maggiore under the influence of the low-level southerly wind. During this displacement, the cell intensifies and grows: it extends up to $6.5 \mathrm{~km}$ altitude with a reflectivity core higher than $42 \mathrm{dBZ}$ at 1750 UTC (Fig. 12(c)). This development lasts about 50 minutes, from 1720 UTC to 1809 UTC (Fig. 12(e)), within updraughts of about 1.5 to $2.5 \mathrm{~m} \mathrm{~s}^{-1}$ (Fig. 12(d) and 12(f)) over Lago Maggiore. It is to be noted that the maximum intensity of updraughts located at around $3.5 \mathrm{~km}$ altitude over the lake at 1750 UTC (Fig. 12(d)) is suggestive of a maximum of convergence below and a maximum of divergence above. Such a cellular structure is characteristic of a convective situation. Consequently, the lake could be considered as a secondary source of moisture. Unfortunately, the location of the three groundbased Doppler radars did not permit observations in the first metres of atmosphere over 
(a)

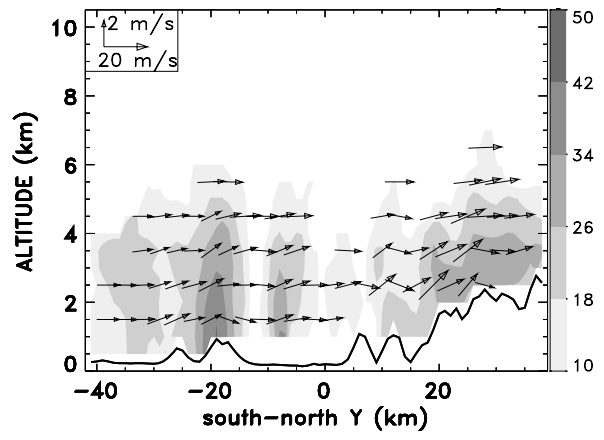

(c)

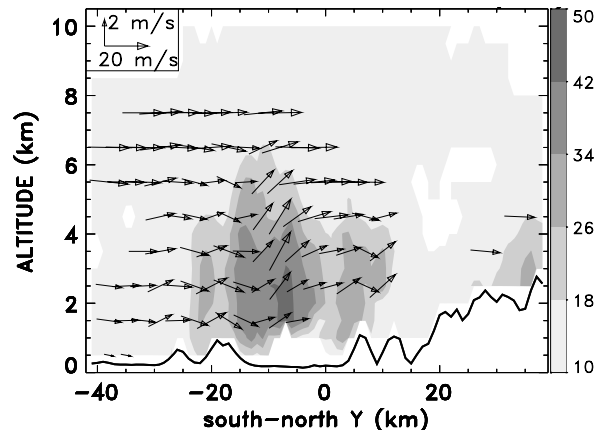

(e)

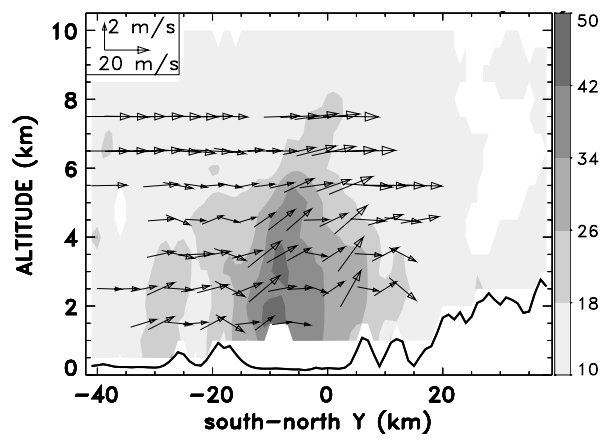

(g)

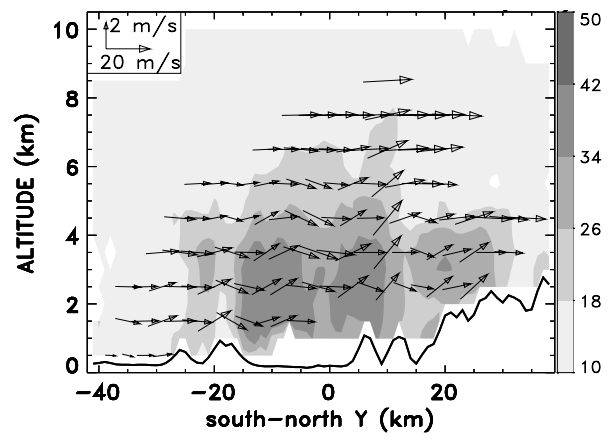

(b)

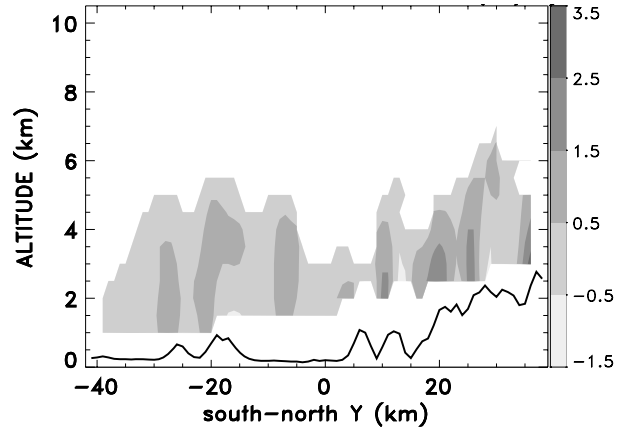

(d)

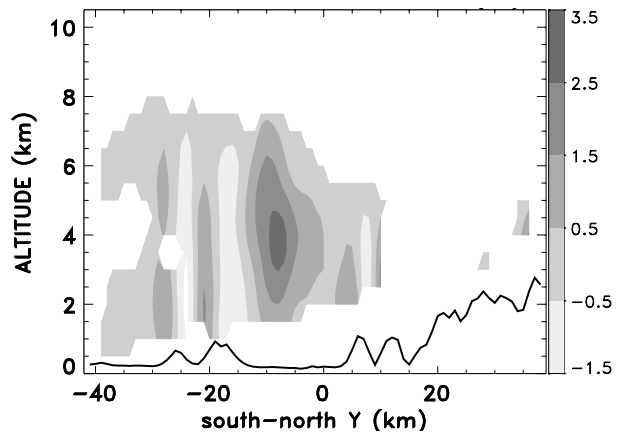

(f)

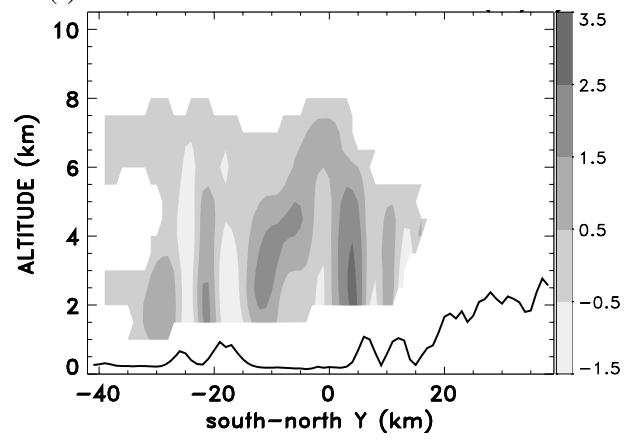

(h)

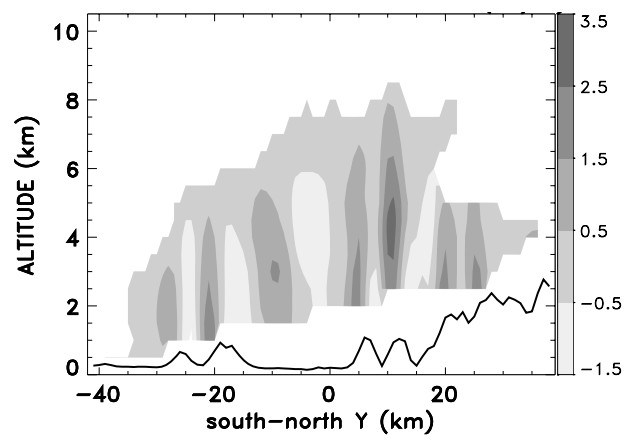

Figure 12. Vertical cross sections at $x=-3 \mathrm{~km}$ of (left panels) wind vectors (reference vectors in upper left corner) with superimposed reflectivity values and of (right panel) vertical velocity at (a), (b) 1720 UTC, (c), (d) 1750 UTC, (e), (f) 1809 UTC, (g), (h) 1830 UTC. Reflectivity and wind velocity are expressed in dBZ and $\mathrm{m} \mathrm{s}^{-1}$ respectively. 
Lago Maggiore, which prevents calculating convergence to verify if it is a maximum over the lake. Precipitation enhancement over both the lake and the peaks of the terrain is confirmed by Fig. 12(g) even if, from this time, convection over the lake is less intense while orographic effects over the peaks are more vigorous (Fig. 12(h)).

\section{(b) Microphysical evolution}

(i) Horizontal cross section. Figure 13 shows the evolution of the hydrometeor distribution at $3 \mathrm{~km}$ altitude, i.e. around $500 \mathrm{~m}$ below the $0{ }^{\circ} \mathrm{C}$ level, over the considered domain. As already observed through the reflectivity field depicted on Fig. 9, three stages can be identified for the precipitation development over the Lago Maggiore target area. From 1720 UTC (Fig. 13(a)) to 1809 UTC (Fig. 13(c)) the precipitation field at $3 \mathrm{~km}$ altitude is characterized by a growing band structure mainly constituted with WS and some embedded GH while the stratiform background associated with lower reflectivity values consists of LR. It is to be noted that GH initially appears within updraughts (not shown) over the upwind side of two peaks located at $(x ; y)=(-25 ;-28)$ and $(-5 ;-22)$.

From 1809 UTC to 1830 UTC, i.e. during the horizontal extension of the precipitating field, the intensification of the area with high reflectivity values (see Figs. 9(c) and 9(d)) consists mainly of wet snow (Fig. 13(d)). Besides, the amount of GH decreases, while during the dissipative stage of the system (after 1830 UTC) characterized by a transformation of WS into LR at $3 \mathrm{~km}$ altitude, the concentration of GH becomes locally a maximum. This increase in GH concentration is probably the result of riming of liquid hydrometeor carried aloft by orographically induced updraughts with falling ice particles. This mechanism is particularly efficient after 1900 UTC as the system arrives over the massif identified by $-25 \mathrm{~km}<x<-18 \mathrm{~km}$ and $-20 \mathrm{~km}<y<0 \mathrm{~km}$ (Fig. 13(e) and 13(f)).

(ii) Meridional cross sections $x=-3 \mathrm{~km}$ and $x=-10 \mathrm{~km}$. A comparative analysis of reflectivity and wind fields (Fig. 12(e)) with the microphysical field (Fig. 14(a)) for the meridional cross-section at $x=-3 \mathrm{~km}$ clearly reveals that, as previously suggested by Houghton (1968), a convective cell is constituted with a hydrometeor column and the development of a cell is concomitant with hydrometeor growth. At low level $(z<3 \mathrm{~km})$, the rapid development from 1720 UTC (Fig. 12(a)) to 1809 UTC (Fig. 12(e)) is characterized by the formation of a narrow column of HR embedded in the growing MR pattern (Fig. 14(a)). This rapid and efficient growth occurs over Lago Maggiore suggesting that it could act as a moisture source, so increasing water content in clouds, and within updraughts (about 1.5 to $2.5 \mathrm{~m} \mathrm{~s}^{-1}$ ) which support rain particles and increase their residence time in the cloud. This indicates coalescence as the main mechanism implied in rain enhancement. By carrying aloft liquid water, updraughts allow formation of graupel particles by riming and freezing as observed at 1809 UTC (Fig. 14(a)) above the $0{ }^{\circ} \mathrm{C}$ level in a $2 \mathrm{~km}$ thick layer heading a hydrometeor column constituted with rain and WS particles. This configuration is similar to that observed by Medina and Houze (2003a) and is in accordance with the numerical results by Yuter and Houze (2003) for IOP $2 \mathrm{~b}$. The presence of $\mathrm{GH}$ at an altitude greater than $3 \mathrm{~km}$ can be explained by an enhancement of updraughts due to latent heat release during the freezing process. It is also to be noted that the presence of HR below the graupel cap may be a consequence of the melt of the falling graupel. This highlights the contribution of the ice phase to heavy precipitation.

From 1830 UTC (Fig. 14(b)), the quantity of GH decreases over the lake and increases over the first peak of the mountains as a consequence of less intense convection 

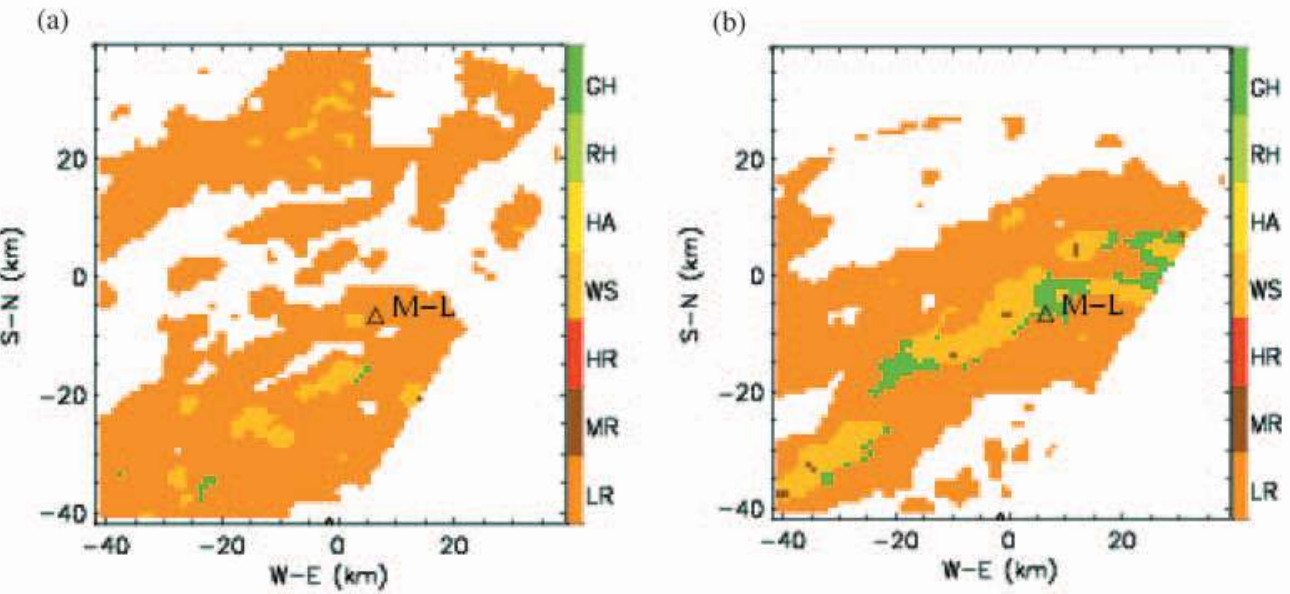

(c)
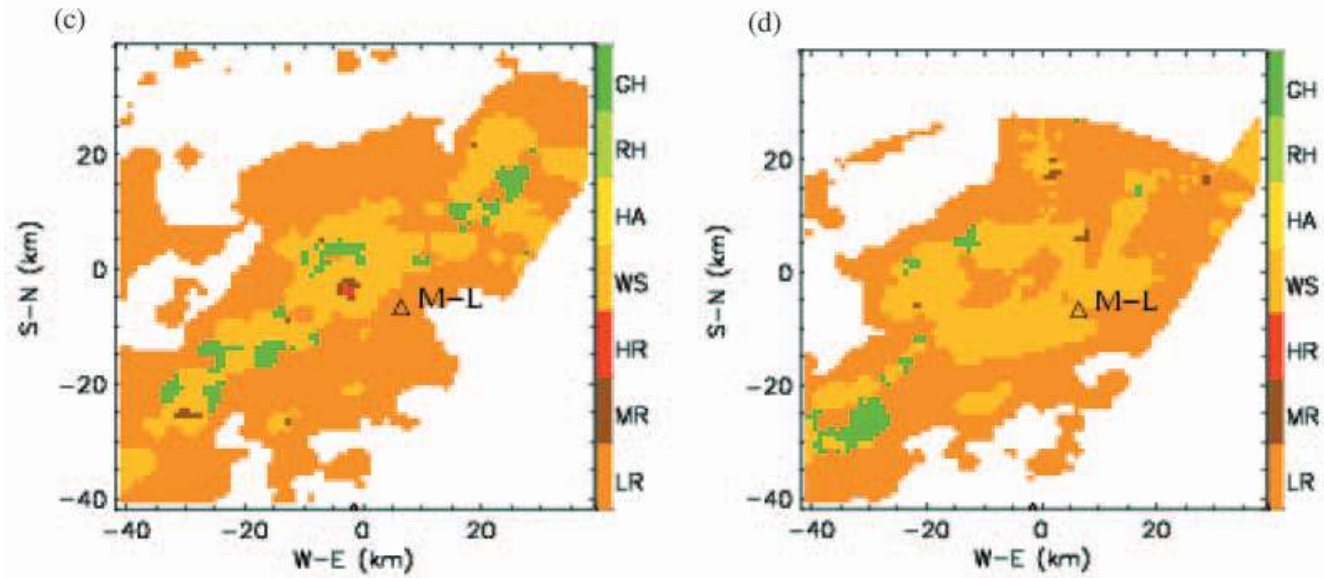

(e)

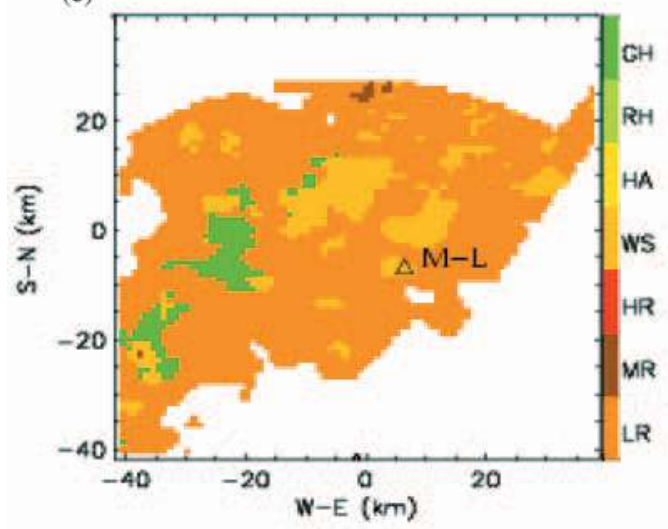

(f)

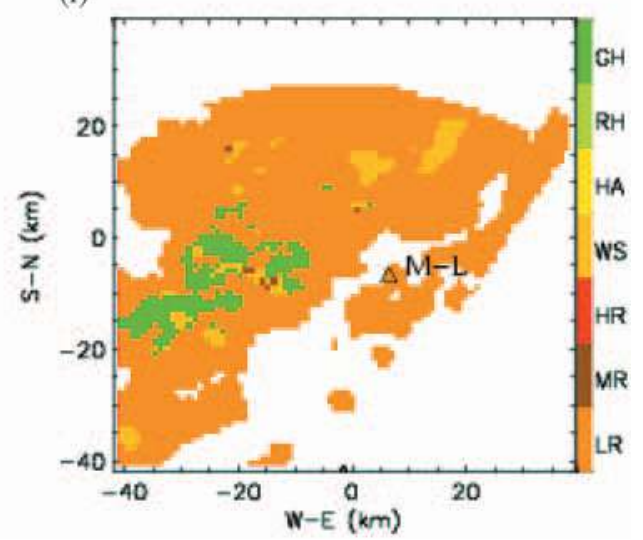

Figure 13. Horizontal cross sections in the Lago Maggiore region at $3 \mathrm{~km}$ altitude of the microphysical fields at: (a) 1720 UTC, (b) 1750 UTC, (c) 1809 UTC, (d) 1830 UTC, (e) 1910 UTC and (f) 1950 UTC. 
(a)

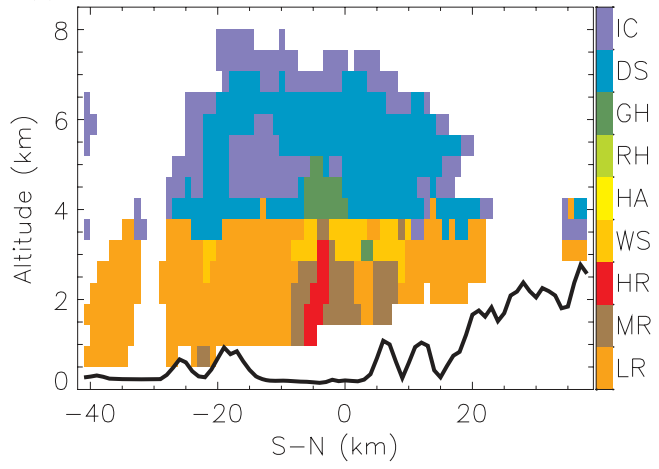

(b)

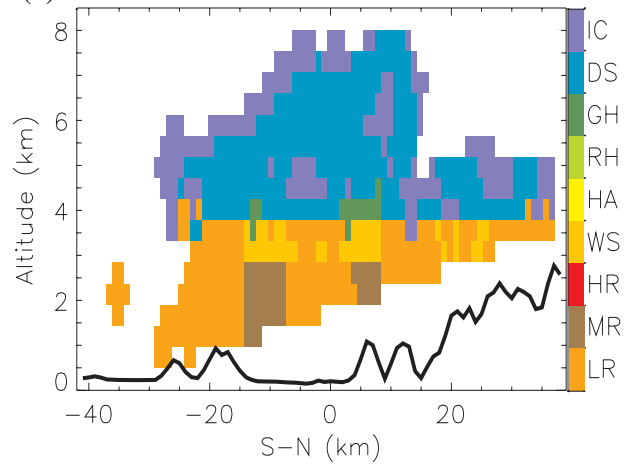

Figure 14. Vertical cross sections at $x=-3 \mathrm{~km}$ of the microphysical fields at: (a) 1809 UTC and (b) 1830 UTC.

(a)

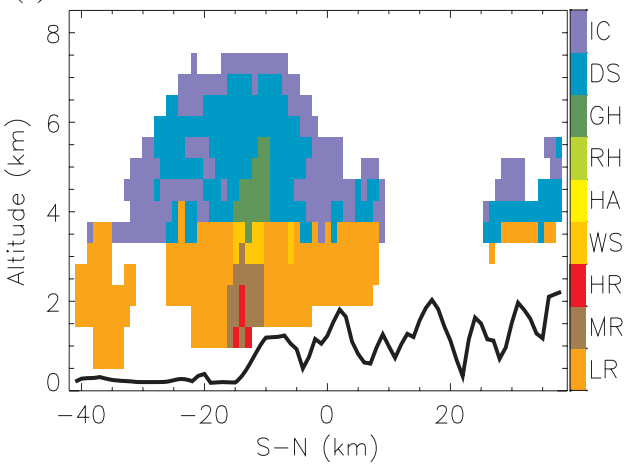

(c)

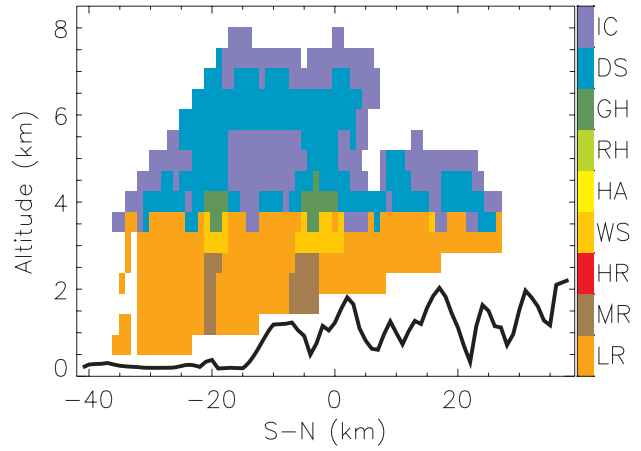

(b)

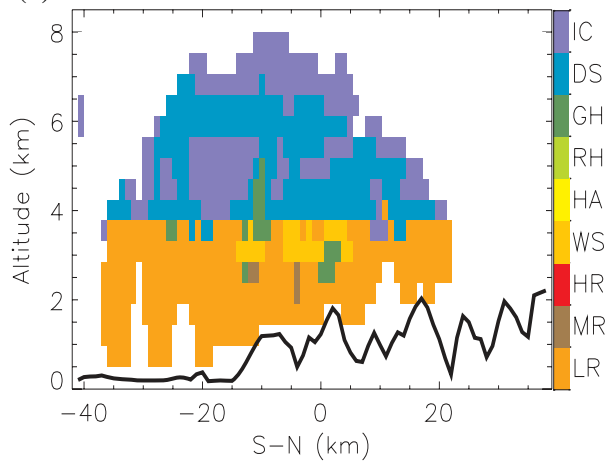

(d)

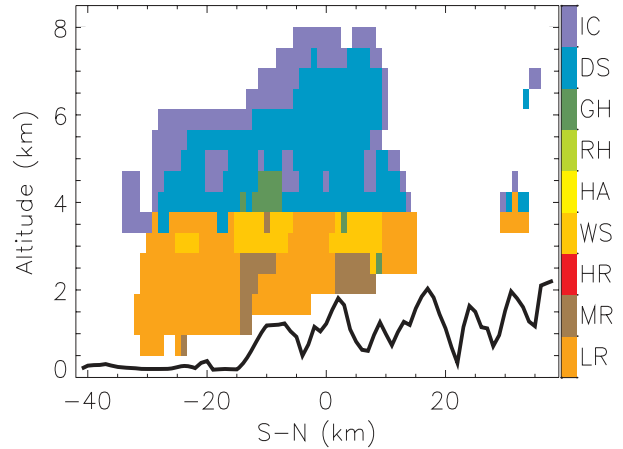

Figure 15. Vertical cross sections at $x=-10 \mathrm{~km}$ of the microphysical fields at: (a) 1750 UTC, (b) 1809 UTC, (c) 1820 UTC and (d) 1850 UTC.

over the lake and an enhancement of orographic effects over the peak (Fig. 12(h)). This observation supports the analysis of Fig. 13 in section 5(b)(i) which emphasizes the role of riming (and updraughts) in $\mathrm{GH}$ formation.

A comparison between Fig. 10 and Fig. 15 shows that the major cell, which quickly developed between 1720 UTC and 1750 UTC over the upslope of the mountains by release of potential instability, consists of a narrow hydrometeor column of MR, WS, 
HR and GH extending up to $5.5 \mathrm{~km}$ altitude. It is interesting to note that the graupel cap exhibits an upwind slope parallel to the upslope of the mountain over which it is located (Fig. 15(a)). This convective cell is a nice illustration of the orographic convective growth conceptual model by Medina and Houze (2003a) illustrated in their Fig. 17(b): presence of heavy precipitation (HR and MR) at low level, WS below the $0{ }^{\circ} \mathrm{C}$ level and a graupel cap above. At 1809 UTC (Fig. 15(b)) the vanishing of HR and MR over the first peak $(y=-12 \mathrm{~km})$ can be related to the decrease of the quantity of GH aloft. On the other hand, it is also important to note the layer of WS over the second peak at $y=2 \mathrm{~km}$. This configuration can be explained by an ejection of hydrometeors from the cell located ten kilometres to the south in which GH is over WS. This analysis can be related to the fountain particles concept of Yuter and Houze (1995); the particles at highest (lowest) altitude in the old cell are then observed at the lowest (highest) altitude in the new cell. This is all the more pertinent as the shape of the hydrometeor distribution above the $0{ }^{\circ} \mathrm{C}$ level is quite consistent with the wind field profile. From 1820 UTC (Fig. 15(c)) to 1850 UTC (Fig. 15(d)), the column of hydrometeors at $y=-5 \mathrm{~km}$ disappears because of its northward motion and of precipitation and ejection of particles over the second mountainous peak at $y=0 \mathrm{~km}$ as suggested by the evolution of the reflectivity and wind field displayed in Fig. 10. This is why a new column of hydrometeors appears at $y=5 \mathrm{~km}$ while the old one at $y=-5 \mathrm{~km}$ is no longer visible at 1850 UTC in Fig. 15(d).

\section{CONCLUSiON}

Four-dimensional kinematic and microphysical investigations of IOP3 (25-26 September) in the Lago Maggiore region has been deduced from data collected with three ground-based Doppler radars (Ronsard, Monte Lema and SPOL). More precisely, this paper focuses on the end of the 25 September afternoon from 1720 UTC to 1950 UTC which corresponds to the most active phase of precipitation. Microphysical study has been performed from the polarimetric data provided by SPOL and analysed through a simplified version of the NCAR hydrometeor classification algorithm by Vivekanandan et al. (1999).

As already mentioned by Medina and Houze (2003b), IOP3 presents high similarities to IOP2b in the synoptic and thermodynamic analyses. In both cases a trough located over the North Atlantic generates a predominant southwesterly flow over the Mediterranean Sea toward the Alps. At low level, air is warm and potentially unstable. The conditions are then propitious for precipitation over the Alps. However, a difference has to be noted in the low-level wind field which consists of a southerly Ligurian Sea flow towards Lago Maggiore during IOP3 and strong easterlies from the Adriatic Sea during IOP2b.

The first part of the present work consists of a temporal mean study of IOP3 through an analysis of the mean 3D wind field and the mean vertical distribution of hydrometeors. Similar characteristics have been emphasized with the mean reflectivity signal analysed by Medina and Houze (2003a). In particular, convective precipitation is primarily localized over Lago Maggiore and the upslope of the first mountain, with reflectivity values of 30 to $35 \mathrm{dBZ}$.

On the other hand, concerning the microphysical structure, rain is observed at positive temperatures, wet snow just below the $0{ }^{\circ} \mathrm{C}$ level, iced particles above, and graupel on either side of the freezing level with, above it, a $2 \mathrm{~km}$ thick layer generally embedded within the dry snow layer. These observations are suggestive of convective processes such as coalescence at positive temperatures, and riming and freezing at negative temperatures, embedded within stratiform processes such as melting of dry snow and graupel leading to wet snow formation and probably to heavy rain. 
In the second part, a four-dimensional kinematic and microphysical analysis of the precipitating system has been carried out. Three periods can be distinguished in the evolution of the system from 1720 UTC to 1950 UTC: a well structured phase (from 1720 UTC to 1809 UTC) during which the system is advected northwards, grows and intensifies over Lago Maggiore, a phase of spreading (from 1809 UTC to 1830 UTC) of precipitation in the vicinity of the mountains, and finally a dissipation phase (from 1830 UTC to 1950 UTC) over the mountains.

Convective cells have been observed to efficiently develop in about 50 minutes not only over the upwind slope of the first peak but also over Lago Maggiore in the presence of updraughts, which seems to indicate that the lake favours local convection. The associated microphysical structure during the first period of precipitation is characterized by a column of hydrometeors with medium rain, heavy rain and graupel from bottom to top. Coalescence at low level (below the $0{ }^{\circ} \mathrm{C}$ isotherm), and riming and freezing above were identified as the major microphysical and physical processes resulting in precipitation. Melting of graupel during its fall is also a major phenomenon leading to heavy precipitation at low level, which highlights the essential role of the ice phase in formation and enhancement of precipitation. These processes are favoured by orographic lifting and by the presence of Lago Maggiore which acts as a moisture source in addition to the Mediterranean Sea. During the phase of spreading, a forward development of the system is observed over the Alps. According to the fountain particles concept by Yuter and Houze (1995), it probably results from an ejection of hydrometeors from old cells whose progression is perturbed by the orography. This may explain the observed unusual structure of some young cells characterized by the presence of graupel below the layer of wet snow in positive-temperature cloud areas.

\section{APPENDIX A}

\section{Radars: main characteristics}

As previously mentioned, three ground-based Doppler radars were operated in the LMTA: the French Ronsard, the Swiss Monte-Lema and the US NCAR SPOL. Their main characteristics are presented in the following table; more details can be found in Binder et al. (1999).

TABLE 1. MAIN CHARACTERISTICS OF THE THREE RADARS USED

\begin{tabular}{cccc}
\hline & & Radars & \\
\cline { 2 - 4 } Characteristics & Ronsard & Monte-Lema & SPOL \\
\cline { 2 - 4 } Nationality & France & Switzerland & USA \\
Location & $8.517^{\circ} \mathrm{E} ; 45.490^{\circ} \mathrm{N}$ & $8.833^{\circ} \mathrm{E} ; 46.042^{\circ} \mathrm{N}$ & $8.730^{\circ} \mathrm{E} ; 45.720^{\circ} \mathrm{N}$ \\
during MAP & Novara & Monte Lema & Vergiate \\
Altitude & $155 \mathrm{~m}$ & $1625 \mathrm{~m}$ & $280 \mathrm{~m}$ \\
Frequency/Wavelength & $5.6 \mathrm{GHz} / 5.3 \mathrm{~cm}$ & $5.44 \mathrm{GHz} / 5.5 \mathrm{~cm}$ & $3 \mathrm{GHz} / 10 \mathrm{~cm}$ \\
Band & $\mathrm{C}$ & $\mathrm{C}$ & $\mathrm{S}$ \\
Type & Doppler & Doppler & Doppler/polarimetric \\
Fields recorded & Reflectivity & Reflectivity & Reflectivity + \\
& Doppler velocity & Doppler velocity & Doppler velocity \\
& & & + particle type \\
Radial coverage & $100 \mathrm{~km}$ & $230 \mathrm{~km}$ & $100 \mathrm{~km}$ \\
Azimuthal coverage & $0^{\circ}$ to $360^{\circ}$ & $0^{\circ}$ to $360^{\circ}$ & Sectorial $120^{\circ}$ \\
Radial resolution & $200 \mathrm{~m}$ & $1000 \mathrm{~m}$ & $150 \mathrm{~m}$ \\
Sampling interval & $10 \mathrm{~min}$ & $5 \mathrm{~min}$ & $10 \mathrm{~min}$ \\
Beam width $(3 \mathrm{~dB})$ & $0.89^{\circ}$ & $1^{\circ}$ & $0.91^{\circ}$ \\
Pulse width & $0.67 \mu \mathrm{s}$ & $0.5 \mu \mathrm{s}$ & $0.35 \mu \mathrm{s}$ \\
Resolution & $100 \mathrm{~m}$ & $75 \mathrm{~m}$ & $38 \mathrm{~m}$ \\
\hline
\end{tabular}




\section{APPENDIX B}

\section{Brief recall of polarimetric variables}

It is well known that polarized waves are very useful to discriminate the scattering hydrometeors in clouds. Indeed, these waves are sensitive to the geometric (size, shape, orientation) and physical (phase, density) mean properties of the scatterers. The SPOL polarimetric Doppler radar uses two linear polarizations (horizontal and vertical) in commutation, with a wavelength of $10 \mathrm{~cm}$. A combination of $Z_{\mathrm{h}}$ and $Z_{\mathrm{v}}$ reflectivities and $\phi_{\mathrm{h}}$ and $\phi_{\mathrm{v}}$ phase shifts relative to both directions (subscripts $\mathrm{h}$ and $\mathrm{v}$ denote horizontal and vertical polarizations, respectively) permits the measurement of four polarimetric variables $(\mathrm{POV})$ :

- The differential reflectivity $Z D R=10 \log \left(Z_{\mathrm{h}} / Z_{\mathrm{v}}\right)$. Because they are spherical (hail) or they are falling without preferential direction (snow and ice crystal), ice particles are characterized by $Z_{\mathrm{h}} \approx Z_{\mathrm{v}}$ and, consequently, $Z D R \approx 0$. On the contrary, because large falling raindrops are oblate they induce an anisotropic scattering of the incident radar beam. In particular, the larger the drops are, the more flattened they are by the aerodynamic effects, which leads to higher positive values for $Z D R$. Thus, $Z D R$ provides information on mean size and shape of hydrometeors and can be used for a discrimination between ice and liquid particles.

- The linear depolarization ratio $L D R=10 \log \left(Z_{\mathrm{hv}} / Z_{\mathrm{hh}}\right)^{*}$ where $\mathrm{Z}_{\mathrm{hv}}$ and $\mathrm{Z}_{\mathrm{hh}}$ are vertical and horizontal reflectivities, respectively, relative to the incident horizontal polarized radar wave. It indicates if the incident wave is depolarized which generally occurs if hydrometeors are asymmetric and/or their horizontal and vertical axis are not principal. Then $L D R$ provides information about mean shape and orientation of hydrometeors.

Both these variables are sensitive to the refractive index $n$. Thus, with the same geometry, wet hydrometeors lead to higher values than dry ones. In particular, if ice particles are covered by water, then deformation of the thin water skin under aerodynamic effects may lead to high values of $L D R$ and $Z D R$, characteristic of large distorted raindrops. Two others parameters are introduced:

- The specific differential phase $K D P$ is the derivative along the optical radartarget path $r_{2}-r_{1}$ of the differential phase (phase shift between horizontal and vertical polarization):

$$
K D P=\left(\phi_{\mathrm{dp}}\left(r_{2}\right)-\phi_{\mathrm{dp}}\left(r_{1}\right)\right) /\left(r_{2}-r_{1}\right) \text { in }\left({ }^{\circ} \mathrm{km}^{-1}\right) \text { with } \phi_{\mathrm{dp}}=\phi_{\mathrm{h}}-\phi_{\mathrm{v}}
$$

$K D P$ provide information about the environment between the radar and the target; it is independent of attenuation and radar calibration.

- The cross correlation factor statistically indicates the diversity in size, shape, orientation, nature and type of hydrometeors in the scanned volume radar. The higher this diversity is, the more this factor decreases.

Further information relative to POV can be found in Straka et al. (2000) or Bringi and Chandrasekar (2001).

\footnotetext{
* The first index indicates the polarization of the incident wave (emitted by the radar), the second indicates the polarization of the backscattered wave (received by the radar). When these waves are identical (in the sense of polarization), only one index is used. It is important to note that $Z_{\mathrm{hv}}$ is smaller than $Z_{\mathrm{hh}}$ (ratio less than $1 \%$ ). So, $L D R$ is negative and very noise sensitive.
} 
Banta, R. M.

1990

Binder, P., Rossa, A., Bougeault, P., Moore, J., Jorgensen, D. and Bolliger, $\mathrm{M}$.

Bougeault, P., Binder, P. and Kuettner, J.

Bougeault, P., Binder, P., Buzzi, A., 2001 Dirks, R., Houze, R., Kuettner, J., Smith, R., Steinacker, R. and Volkert, $\mathrm{H}$ Bousquet, O. and Smull, B. F.

Bringi, V. N. and Chandrasekar, V.

Chang, J.-T. and Wetzel, P. J.

Chen, F., Warner, T. T. and Manning, $\mathrm{K}$.

Chong, M., Georgis, J.-F., Bousquet, O., Brodzik, S. R., Burghart, C., Cosma, S., Germann, U., Gouget, V., Houze, R. A., Jr., James, C. N., Prieur, S., Rotunno, R.,

Roux, F., Vivekanandan, J. and Zeng, Z.-X.

Cotton, W. R., George, R. L. and Knupp, K. R.

Frei, C. and Schaer, C.

Garrett, A. J.

Georgis, J.-F., Roux, F., Chong, M. and Pradier, $\mathrm{S}$.

Houghton, H. G.

Houze, R. A., Jr.

Kessler, E.

Kristovich, D. A. R. and coauthors

Mahfouf, J. F., Richard, E. and Mascart, $\mathrm{P}$

Massacand, A. C., Wernli, H. and Davies, H. C.

Medina, S. and Houze, R. A., Jr.

Mendel, J. M.

1995

Pradier, S., Chong, M. and Roux, F. 2002

2003

2001

2003

1968

1997

1969

2000

1987

1998

\section{REFERENCES}

The role of mountain flows in making clouds. Pp. 229-283 in Atmospheric processes over complex terrain, Meteorological Monographs, 23, American Meteorological Society

1999 MAP Implementation Plan. Version 4.1, 260 pp. (Available from MAP Data Centre, ETH, Zürich, CH-8093, Switzerland)

MAP Science Plan, 64 pp. (Available from MAP Data Centre, ETH, Zürich, CH-8093, Switzerland)

The MAP special observing period. Bull. Am. Meteorol. Soc., 82, 433-462

Observations and impacts of upstream blocking during a widespread orographic precipitation event. Q. J. R. Meteorol. Soc., 129, 391-409

Polarimetric Doppler weather radar: principles and applications. Cambridge University Press

1991 Effects of spatial variations of soil moisture and vegetation on the evolution of a prestorm environment: A numerical case study. Mon. Weather Rev., 119, 1368-1390

2001 Sensitivity of orographic moist convection to landscape variability: A study of the Buffalo Creek, Colorado, flash flood case of 1996. J. Atmos. Sci., 58, 3204-3223

2000 Real-time wind synthesis from Doppler radar observations during the Mesoscale Alpine Program. Bull. Am. Meteorol. Soc., 81, 2953-2962

An intense, quasi-steady thunderstorm over mountainous terrain. Part I: Evolution of the storm-initiating mesoscale circulation. J. Atmos. Sci., 39, 328-342

A precipitation climatology of the Alps from high-resolution raingauge observations. Int. J. Climatol., 18, 873-900

1982 A parameter study of interactions between convective clouds, the convective boundary layer, and a forested surface. Mon. Weather Rev., 110, 1041-1059

Triple-Doppler radar analysis of the heavy rain event observed in the Lago Maggiore region during MAP IOP2b. $Q . J . R$. Meteorol. Soc., 129, 495-522

$2003 a$

$2003 b$

On precipitation mechanisms and their artificial modification. J. Appl. Meteorol., 7, 851-859

Stratiform precipitation in regions of convection: a meteorological paradox? Bull. Am. Meteorol. Soc., 78, 2179-2196

On the distribution and continuity of water substance in atmospheric circulations. Meteorological Monographs, 10, American Meteorological Society

The Lake-Induced Convection Experiment and the Snowband Dynamics Project. Bull. Am. Meteorol. Soc., 81, 519-542

The influence of soil and vegetation on the development of mesoscale circulations. J. Appl. Meteorol., 26, 1483-1495

Heavy precipitation on the Alpine southside: an upper-level precursor. Geophys. Res. Lett., 25, 1435-1438

Air motions and precipitation growth in Alpine storms. Q. J. R. Meteorol. Soc., 129, 345-371

Orographic precipitation in potentially unstable Alpine storms: Map IOPs 2b, 3, and 5. Preprint, ICAM/MAP Meeting, Brig, Switzerland, 19-23 May

Fuzzy logic systems for engineering: a tutorial. Proc. IEEE, 83, 345-377

Radar observations and numerical modeling of a precipitating line during MAP IOP5. Mon. Weather Rev., 130, 2533-2553 
Pradier, S., Chong, M. and Roux, F. 2004

Raymond, D. J. and

Wilkening, M. H.

Rotunno, R. and Ferretti, R.

Scott, R. W. and Huff, F. A.

Segal, M., Schreiber, W. E., Kallos, G., Garratt, J. R., Rodi, A., Weaver, J. and Pielke, R. A.

Smith, R. B.

Straka, J. M., Zrnic, D. S. and Ryzhkov, A. V.

Vivekanandan, J., Zrnic, D. S., Ellis, S. M., Oye, R., Ryzhkov, A. V. and Straka, J.

Yuter, S. E. and Houze, R. A., Jr.
1982

2003

1996

1989

1979

2000

1999

1995

2003

Characteristics of some frontal stratiform precipitation events south of the alpine chain during MAP. Meteorol. Atmos. Phys., 87, 197-218

Flow and mixing in New Mexico mountain cumuli. J. Atmos. Sci., 39, 2211-2228

Orographic effects on rainfall in MAP cases IOP2b and IOP8. Q. J. R. Meteorol. Soc., 129, 373-390

Impacts of the Great Lakes on regional climate conditions. J. Great Lakes Res., 22, 845-863

The impact of crop areas in northeast Colorado on midsummer mesoscale thermal circulations. Mon. Weather Rev., 117, 809-825

The influence of mountains on the atmosphere. Adv. Geophys., 21, $87-230$

Bulk hydrometeor classification and quantification using polarimetric radar data: synthesis of relations. J. Appl. Meteorol., 39, 1341-1372

Cloud microphysics retrieval using S-band dual-polarization radar measurements. Bull. Am. Meteorol. Soc., 80, 381-388

Three-dimensional kinematic and microphysical evolution of Florida cumulonimbus. Part III: Vertical mass transport, mass divergence and synthesis. Mon. Weather Rev., 123, 1964-1983

Microphysical modes of precipitation growth determined by S-band vertically pointing radar in orographic precipitation during MAP. Q. J. R. Meteorol. Soc., 129, 455-476 